UPPSALA
Working Paper 2005:15

Department of Economics

Do Benefit Hikes Damage Job Finding? Evidence from Swedish Unemployment Insurance Reforms

Helge Bennmarker, Kenneth Carling and Bertil Holmlund 
Department of Economics

Uppsala University

P.O. Box 513

SE-751 20 Uppsala

Sweden

Fax: +4618471 1478
Working paper 2005:15

April 2005

ISSN 0284-2904

Do Benefit Hikes Damage Job Finding?

EVIDENCE FROM SWEDISH UNEMPLOYMENT INSURANCE REFORMS

Helge Bennmarker, Kenneth Carling and Bertil Holmlund

Papers in the Working Paper Series are published on internet in PDF formats.

Download from http://www.nek.uu.se

or from S-WoPEC http://swopec.hhs.se/uunewp/ 


\title{
Do Benefit Hikes Damage Job Finding? Evidence from Swedish Unemployment Insurance Reforms ${ }^{\ddagger}$
}

\author{
by
}

\author{
Helge Bennmarker, ${ }^{*}$ Kenneth Carling ${ }^{\S}$ and Bertil Holmlund ${ }^{\dagger}$
}

This draft: March 29, 2005

\begin{abstract}
In 2001 and 2002, Sweden introduced several unemployment insurance reforms. A major innovation in the first reform was the introduction of a two-tiered benefit structure for some unemployed individuals. This system involved supplementary compensation during the first 20 weeks of unemployment. The 2002 reform retained the two-tiered benefit structure but involved also substantial benefit hikes for spells exceeding 20 weeks. This paper examines how these reforms affected transitions from unemployment to employment. We take advantage of the fact that the reforms had quasi-experimental features where the "treatments" differed considerably among unemployed individuals. We find that the reforms had strikingly different effects on job finding among men and women. The two reforms in conjunction are estimated to have increased the expected duration of unemployment among men but to have decreased the duration of unemployment among women. The overall effect on the duration of unemployment is not statistically different from zero. However, the reforms reduced job finding among males who remained unemployed for more than 20 weeks.
\end{abstract}

Keywords: Unemployment duration; Unemployment benefits.

JEL classification: J64; J65.

\footnotetext{
¥ We are grateful for useful comments from seminar participants at IFAU Uppsala, Humboldt University Berlin and UBC Vancouver, as well as from session participants in the EALE and SOLE meetings 2004.

* Institute for Labour Market Policy Evaluation (IFAU), Box 513, SE-751 20 Uppsala, SWEDEN.

E-mail: Helge.Bennmarker@ifau.uu.se

$\S$ Institute for Labour Market Policy Evaluation (IFAU), Box 513, SE-751 20 Uppsala, SWEDEN

E-mail: kca@du.se

† Department of Economics, Uppsala University, Box 513, SE-751 20 Uppsala, SWEDEN.

E-mail: Bertil.Holmlund@nek.uu.se
} 


\section{Introduction}

Recent Swedish unemployment insurance (UI) policies have been closely related to the overall macroeconomic development. When a deep recession hit the economy in the early 1990s, surging budget deficits motivated decisions to reduce the generosity of the UI system. When the economy had recovered by the early 2000s, the previous policies were reversed and several reforms increased the generosity of unemployment compensation. A noticeable feature of the reforms in 2001 was the introduction of two-tiered benefit structures where compensation declined to a lower level after 20 weeks of elapsed duration of unemployment. The two-tiered structure was implemented by means of a substantial (+17 percent) increase in benefits for spells up to 20 weeks. The 2002 reform involved equally substantial benefit hikes for spells exceeding 20 weeks in addition to some further rises in benefits for spells up to 20 weeks.

The purpose of this paper is to examine how these recent reforms have affected job finding. Since the reforms entailed large benefit increases for some unemployed individuals, there is a presumption that we should observe a fall in job finding rates. However, the fact that the reforms affected the time profile of benefit receipt cautions against too quick conclusions. It is well known, at least since the seminal paper by Mortensen (1977), that higher benefits may actually increase job finding among some unemployed individuals to the extent that they are forward-looking and recognize that future employment spells carry layoff risks. For a person who is not qualified for UI, a rise in the benefit level makes it more valuable to be employed since employment qualifies for future UI receipt. By analogy, supplementary benefits for the short-term unemployed should increase the value of employment relative to the value of unemployment for the long-term unemployed and therefore speed up their job finding. This entitlement effect may actually influence behavior also among those who have not yet exhausted their supplementary benefits.

Identification of policy effects is facilitated by the fact that the aforementioned benefit hikes did not apply to all unemployed and insured individuals. A key policy parameter is the cap on the benefit level. This cap was raised in 2001 as well as in 2002 and the hikes varied depending on elapsed duration. To identify effects of the benefit reforms we adopt a difference-indifferences strategy and compare the probability of entering employment before and after the reform for those affected by the benefit hikes - the treatment groups - with the job finding 
probability for those who were not affected - the control group. The credibility of this identification strategy is enhanced by the fact that the reforms were introduced during a period with considerable stability in the macroeconomic conditions. The risk that the estimated effects are subject to policy endogeneity is remote since the benefit hikes did not target groups with above-average unemployment (or above-average increases in unemployment).

The effects of introducing a two-tiered benefit structure are of general interest. Moreover, the reforms should improve the possibility of identifying entitlement effects associated with more generous benefits. Previous studies of the effects of UI compensation have typically ignored that the usual disincentive effect may be counteracted by an entitlement effect. ${ }^{1}$ Our data allow us to provide tests for entitlement effects. The empirical relevance of entitlement effects is crucial when designing UI policy. A significant fraction of the unemployed do not receive any UI compensation at all; this holds for the U.S. as well as for European countries. Failure to identify entitlement effects, if they are present, will lead the researcher to overestimate the adverse unemployment effects of UI benefits. Entitlement effects are also important in welfare analyses of UI. Indeed, the normative rationale for a two-tiered benefit structure may be critically dependent on the presence of entitlement effects. ${ }^{2}$

There is one or two earlier studies of Swedish benefit reforms during the 1990s that adopt reasonably credible identification strategies. ${ }^{3}$ A noteworthy feature of the recent reforms is that the benefit hikes were fairly large for the treated groups. We examine how the reforms affected the path of job finding over the spell of unemployment as well as the implied effects on the expected duration of unemployment. We find fairly large negative effects on expected duration among men that were affected by the benefit hikes; the estimated combined effect of the two reforms on male duration amounts to an increase by 4 to 7 weeks. Somewhat surprisingly, the estimated effect on female unemployment duration is negative. The overall effect on

\footnotetext{
${ }^{1}$ One of the very few exceptions in the duration literature is Katz and Meyer (1990) who include an interaction between time until exhaustion and the benefit level, finding no significant effect. An older somewhat related literature examined whether more generous UI encourages labor force participation (Hamermesh, 1979, 1980). 2 See, e.g., the analysis of optimal UI in Fredriksson and Holmlund (2001).

${ }^{3}$ Harkman (1997) examined the effect of the 1993 cuts in replacement rates, using unemployed workers without UI compensation as control group. This approach can be problematic, however, since recipients and nonrecipients face different incentives. Carling et al (2001) studied the 1996 cut in the statutory replacement rate from 80 to 75 percent, using a methodology similar to the one adopted in this paper.
} 
unemployment duration is not statistically different from zero, but the reforms significantly reduced job finding among males who remained unemployed for more than 20 weeks.

We begin in the next section by describing the Swedish UI system and the changes that are of particular relevance for our study. Section 3 discusses the theoretical issues and section 4 presents the data: The empirical results are presented in section 5 and section 6 concludes.

\section{Unemployment Insurance and Unemployment in Sweden}

\subsection{Unemployment Insurance}

Our analysis is confined to unemployed individuals entitled to UI payments. The Swedish system is based on voluntary membership in union affiliated UI funds that are subject to detailed government regulations. The UI funds are subsidized so that membership fees are fairly low. Most workers participate in UI through their unions - union density among workers has hovered above or around 80 percent - in which case the provision of UI is part of the package of services obtained through membership. The total membership of the UI funds amounts to around 90 percent of the total labor force and the coverage of UI has shown a trend increase. In 2002, some 75 percent of persons classified as unemployed according to the labor force surveys were members of UI funds. Close to 70 percent of the unemployed registered at the employment exchange offices received UI in the mid-1990s. ${ }^{4}$

UI payments have in theory been of fixed duration. The statutory maximum period of benefit receipt is 60 weeks for most workers (or 300 days since benefits are paid out for five days per week). Benefits are generally not affected by transitions between "open” unemployment and active labor market programs. If a benefit period of 60 weeks has been exhausted, there is a possibility of entering a program or being offered another period of 60 weeks (although without any supplementary benefits). The maximum benefit period is thus in practice “quasi-fixed": the general rule is that the insured worker is entitled to 60 weeks of benefit receipt but the period can be extended by discretionary decisions taken at the labor market offices.

\footnotetext{
${ }^{4}$ Detailed information on the UI funds is available in annual publications from the insurance unit of the National Labor Market Board. The regular labor force surveys include information on UI fund membership among the unemployed. See also SOU 1996:51.
} 
For each new decision on a benefit period, there is a waiting period of five days before benefits are paid out. A benefit period of 60 weeks can comprise several unconnected unemployment spells. If an unemployment spell is interrupted by, say, episodes of employment or education for a period shorter than 12 months, the reentry into unemployment is associated with compensation from the first day within the same benefit period of 60 weeks. A brief employment (education) spell followed by unemployment reentry does not restart the "benefit clock” at zero; instead, the number of remaining days of benefit receipt is reduced by the number of benefit days used up in the earlier unemployment spells within the benefit period. A benefit period of 60 weeks can therefore extend of several years. Individuals entering unemployment in a particular week will generally have different times to benefit exhaustion because of diverse unemployment histories. ${ }^{5}$

By the early 1990s, the maximum replacement rate among workers eligible for UI amounted to 90 percent of previous earnings. ${ }^{6}$ The replacement rate was reduced to 80 percent from the $1^{\text {st }}$ of July 1993 and was further reduced to 75 percent from the $1^{\text {st }}$ of January 1996. In the wake of the public-sector fiscal consolidation in the late 1990s, a decision was taken to raise the UI replacement rate to 80 percent from September 1, 1997. This statutory replacement rate has remained constant over the period 1997-2003.

The Swedish UI system, like most other UI systems, is characterized by a progressive benefit schedule, making effective replacement rates higher for workers with low earnings than for those with high earnings. The progressive schedule is accomplished by means of a cap on the benefit level. Benefit levels below the threshold earnings level are given by the statutory replacement rate multiplied by previous earnings. The benefit cap was reduced in 1993 and remained constant until the end of 1997 when a modest rise was undertaken. The combination of roughly constant benefit caps and continuous nominal wage growth over the 1990s produced a substantial fall in effective replacement rates for workers with above-average earnings.

\footnotetext{
${ }^{5}$ A work requirement for benefit receipt is at least 420 hours of work during the 12-month period preceding unemployment. If a benefit period of 300 days is exhausted, it is possible to continue with a new benefit period provided that the work requirement is fulfilled. This new benefit period involves a waiting period of five days before benefits are received.

${ }^{6}$ Benefits are taxable income and Swedish taxes on labor earnings are progressive. The tax schedule has three segments with different marginal tax rates, the lowest segment involving only municipal proportional taxes. The
} 
Figure 1 shows replacement rates by wage percentiles, revealing a decline for the $75^{\text {th }}$ percentile by 20 percentage points between 1993 and 2000. Median-earners fared better although their replacement rates fell by 10 percentage points over the second half of the 1990s.

Figure 1. Replacement rates by wage percentile, 1992-2002.

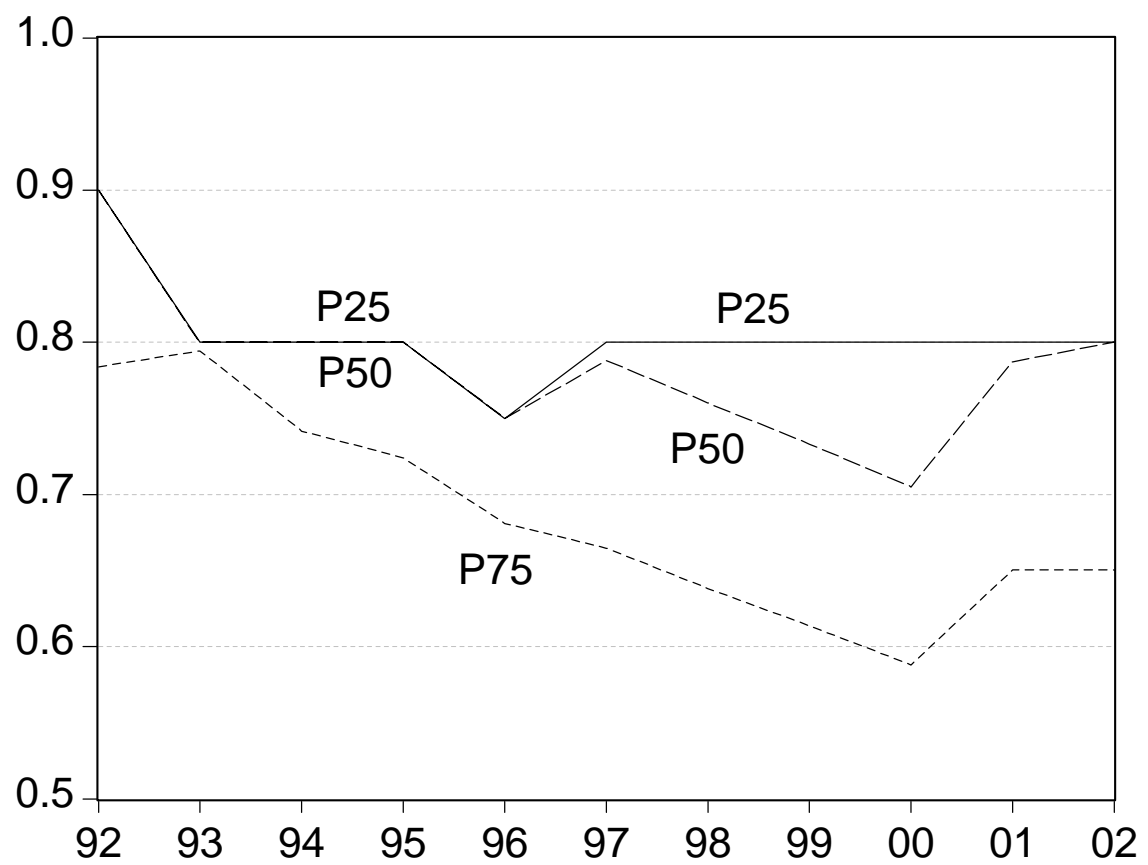

Notes: P25 (P50, P75) is percentile $25(50,75)$. Computations based on maximum daily benefits (multiplied by 22) as of December 31 each year (except for 1993 which pertains to the annual average). Monthly earnings pertain to currently employed workers. P25 coincides with the statutory replacement rate.

Sources: The National Labour Market Board, insurance unit, and Statistical Yearbook of Wages and Salaries, Statistics Sweden.

The process of gradually increasing progressivity of the benefit system was partially reversed by the benefit reforms of 2001 and 2002. The reforms involved increases of the benefit ceilings as well as the introduction of a two-tiered benefit structure. For median earners, the benefit hikes amounted to a 10 percentage point increase in the effective replacement rate (for short unemployment spells). It should be noted that the replacement rate patterns shown in the figure are based on the wage distribution among currently employed workers. The trend decline in effective replacement rates is almost certainly less pronounced among representative

sample we choose to focus on in the present study will be dominated by workers who are only confronted with municipal taxes. 
unemployed individuals since their (pre-unemployment) wages are typically lower than wages among currently employed workers.

Figure 2 illustrates the two reforms in some detail. Benefits vary with earnings at a statutory rate of 80 percent up to a ceiling determined by previous earnings. ${ }^{7}$ In 2000 this ceiling kicks in at a daily (monthly) wage of 725 SEK (15 950 SEK), implying a maximum daily benefit level of 580 SEK. ${ }^{8}$ From July $1^{\text {st }}$ 2001, the earnings threshold was raised to 850 SEK per day (18 700 SEK per month) - but only for the first 20 weeks of insured unemployment. This translates into a benefit ceiling of 680 SEK per day for the first 20 weeks, as illustrated in the left part of the figure. The increase in the benefit ceiling (100 SEK) amounted to 17.2 percent. The 2001 reform thus introduced a two-tiered benefit structure. We refer to the additional compensation for the first 20 weeks as supplementary benefits and compensation over the remaining spell as regular benefits.

The 2002 reform, taking effect from the $1^{\text {st }}$ of July 2002, involved two changes. The benefit ceiling for the first 20 weeks was raised by 50 SEK (7.4 percent) from 680 to 730 SEK, corresponding to a rise in the earnings threshold from 850 to 912.50 SEK (18 700 to 20075 in terms of monthly earnings). In addition, the ceiling was raised by 100 SEK (17.2 percent) for durations exceeding 20 weeks. For workers above the earnings threshold, the benefit system in place after the 2002 reform thus involves an initial period of 730 SEK per day followed, after 20 weeks, by 680 SEK until benefit exhaustion.

Figure 2 also illustrates how individuals can be allocated into treatment and control groups. Individuals in group $A$ are referred to as the control group whereas groups $B, C$ and $D$ - that are all subject to treatment in the form of higher benefits - are referred to as treatment groups. Our general strategy for identifying the effects of the reforms will be to compare the evolution of job finding rates among control and treatment groups around the reform dates.

The 2001 reform also introduced changes regarding search requirements and benefit sanctions. These changes took effect already from February 5, 2001. The reform implied that a benefit

\footnotetext{
${ }^{7}$ There is also a floor on the benefit level, implying that very low earnings are not covered by UI benefits.
} 
recipient could restrict job search to his or her occupation and local labor market during the first 20 weeks of unemployment. After this period, the search area has to widen. In some sense, these new rules represented a move towards increased generosity since the previous system involved no rights to restrict search. In practice, however, it may well have been the case that rules allowing restricted search were applied also before 2001, at least over the first weeks of unemployment.

Figure 2. Swedish UI systems 2000 - 2002.

\section{Benefit}

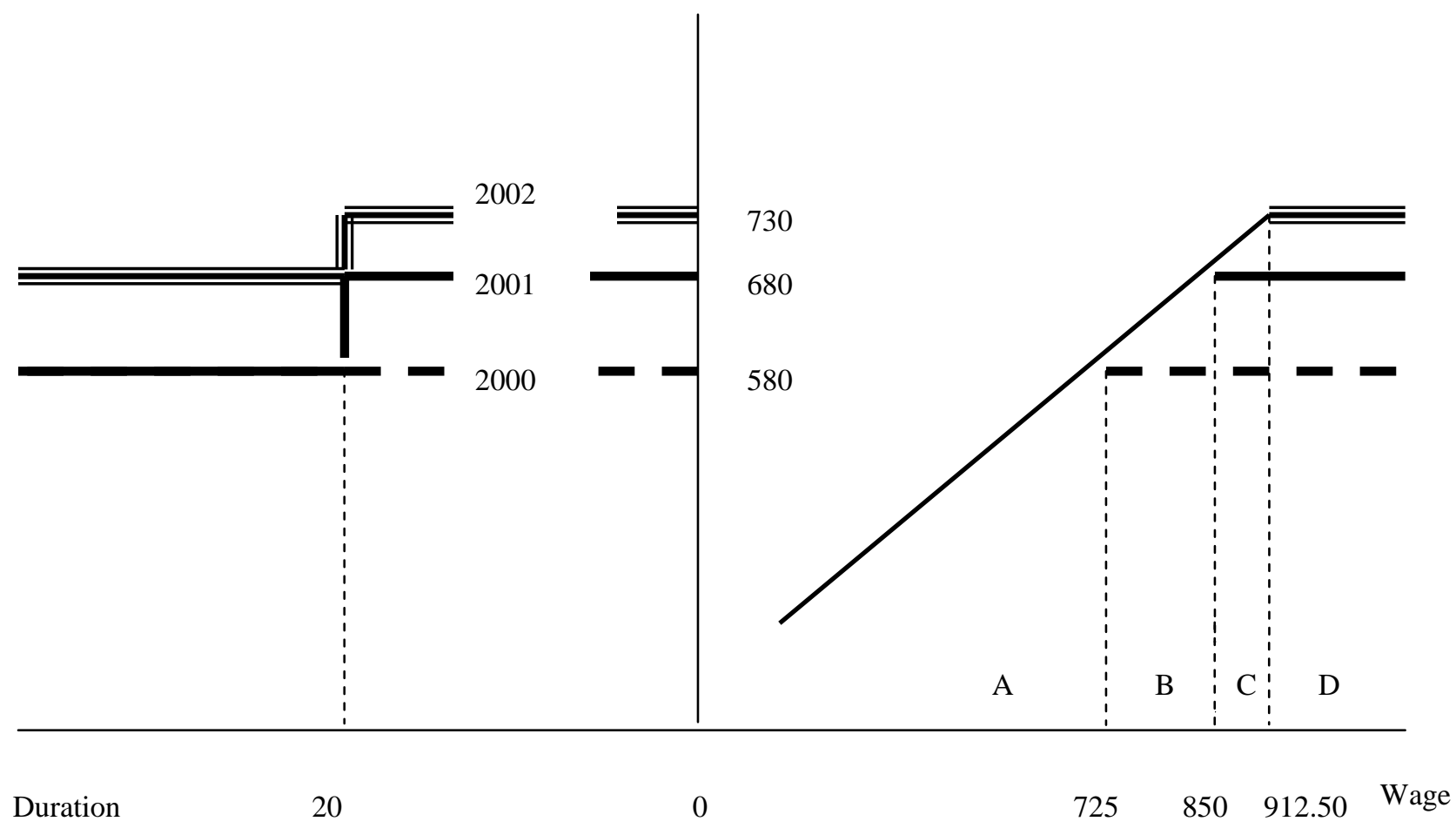

The 2001 reform set the maximum UI period to 60 weeks for all eligible unemployed, irrespective of age (compared to 90 weeks for older workers in the previous system). Furthermore, participation in a labor market program could no longer serve as a qualification for UI. The rules for sanctioning an unemployed individual who does not pursue active search were also changed in 2001. The previous system entailed fairly harsh punishment for failure to

\footnotetext{
8 At exchange rates prevailing in early 2005, 580 SEK amounts to 64 EURO and 84 USD. Benefits are paid out
} 
meet search requirements (complete withdrawal of benefits for a certain time period). The new system involves milder sanctions (such as a reduction of benefits by 25 or 50 percent), the idea being that sanctions should be enforced more frequently.

An evaluation of the effects of the new rules concerning search requirements and sanctions is made difficult by the policy design: all insured and unemployed workers were affected and there are thus no obvious treatment and control groups in this case. We have chosen to include only unemployment spells that started after February 5, 2001, thereby reducing the risk that estimated benefit effects capture the impact of the new rules pertaining to search requirements and sanctions.

Outside the public UI system, there are also UI programs determined by collective agreements between union and employer federations. These programs offer additional benefits for workers with relatively high earnings, thus effectively lifting the caps on benefits beyond the level provided by the public UI system. These programs have had fairly limited coverage of unemployment spells. ${ }^{9}$ Our data contain no information on these additional benefits but it should be noted that negotiated benefits are more likely to be relevant for the treatment than for the control groups. If anything, their disproportionate presence in the treatment groups should lead to an understatement of policy effects (since the treatment "dose" may be understated for some of the individuals exposed to the benefit reforms).

\subsection{Child Care Reforms}

Along with the UI reforms in 2001 and 2002, Sweden introduced reforms concerning child care that arguably could affect labor supply incentives on the intensive as well as the extensive margins (Skolverket 2003, 2004). Subsidized child care includes full-time day care for preschool children and school child care for children six years or older. Day care for pre-school children is utilized by a majority of the parents. Local governments provide these services,

for five days a week and daily income is translated into monthly income by a factor of 22 .

${ }^{9}$ A major agency in this area is Trygghetsrådet which provides support to private-sector white-collar workers. Trygghetsrådet has in recent years provided additional benefits to some 10000 persons per year. By comparison, more than 500000 persons per year have received regular UI payments. Employees in the central government sector are also eligible for supplementary unemployment benefits, administered by Trygghetsstiftelsen. However, only about 1200 persons received such benefits in 2002. (Information from Trygghetsrådet and Trygghetsstiftelsen.) 
subject to various regulations imposed by the central government. The users of day care pay fees that vary by parental income, thus contributing to an increase in the effective marginal tax on market work. The day care fees have also varied substantially across municipalities.

The central government regulations were further stiffened in 2001 and 2002. The first reform was targeted at unemployed parents, who before the reform were not guaranteed municipal child care for their children. A new law, in effect from the $1^{\text {st }}$ of July 2001, guaranteed child care for unemployed parents (at least three hours per day or 15 hours per week). The policy appeared to have affected utilization of day care services among the unemployed: the fraction of children with unemployed parent(s) using day care increased from 58 to 76 percent between 1999 and 2002. The second reform, in effect from the $1^{\text {st }}$ of January 2002, established maximum user fees for parents using day care services. The reform was implemented by subsidies to municipalities and virtually all municipalities decided to immediately introduce the maximum fees. In 2003, all municipalities had implemented the new system. There is evidence that the 2002 reform caused a general fall of user fees and also a substantial reduction in the dispersion of fees across municipalities.

The child care reform pertaining to unemployed parents may have facilitated job search and perhaps partly offset the adverse incentive effects of the 2001 benefit reform. However, this is problematic for our evaluation of UI reforms only to the extent that it had differential effects across the earnings distribution, thus causing different responses among treatment and control groups. It is possible that the marginal productivity of search, in terms of job finding, is generally higher for individuals with more favorable labor market opportunities. If so, the 2001 child care reform would probably tend to attenuate any estimated disincentive effects of the 2001 benefit reform.

The maximum fee system of 2002 might affect job search incentives via an unemployed parent's consumption possibilities while unemployed as well as her consumption possibilities when employed; the latter effect is probably more important than the former since unemployed individuals are less likely to be directly affected by the cap on fees. There is a presumption that the new system should be particularly likely to affect behavior among unemployed parents with relatively high market earnings; the cap on fees should increase the rewards from work relative 
to non-work more for them than for those who are not affected by the cap because of relatively low potential earnings.

We have not been able to satisfactorily control for the possible effects of the child care reforms. There is no information in the data on the number of pre-school children and on how day care fees have changed at the individual level. We will however present results separately for men and women. If the child-care reforms have attenuated adverse incentive effects of the UI reforms, we should most likely find such attenuation among unemployed women since women spend more time in child care than men do.

\subsection{Unemployment, Employment and Policy Endogeneity}

Evaluations of major UI reforms are arguably difficult if the reforms are implemented in a turbulent macroeconomic environment. The period under consideration is by reasonable measures closer to stability than turbulence, however. By the year 2000, Sweden had largely recovered from the severe recession of the early 1990s when unemployment had hit doubledigit levels. Over the period 2001 - 2002, the period of our investigation, the unemployment rate displayed very little (non-seasonal) variation except for a small rise by the end of 2002 (Figure 3). The employment-to-population rate displayed a weak negative development for most of the period.

Aggregate unemployment and employment may be influenced by the UI reforms and therefore perhaps be problematic as indicators of the macroeconomic environment. However, the picture is very similar if we look at vacancy data. Both the stock of unfilled vacancies and the inflow of new vacancies show negligible trends over the period of our investigation (Figure 4).

Are there any signs of marked differential evolution of employment and unemployment among demographic groups? Table 1 shows the key statistics by age and education. There are some signs of worsening labor market conditions for youths in 2002, reflecting the fact that youths tend to be more affected (at least in absolute terms) when the aggregate labor market deteriorates. All in all, however, the overall pattern is one of considerable stability. 
As already noted, one can argue that Swedish UI reforms since the early 1990s have been triggered by macroeconomic conditions. The cuts in replacement rates in 1993 and 1996, as well as the nominal freeze on benefit ceilings over most of the decade were motivated by the desire to regain control over surging government budget deficits induced by the slump of the early 1990s. The rebound in benefit generosity, starting in 1997 and continuing by the reforms in 2001 and 2002, was perceived as feasible when government finances had been brought under control. UI generosity in Sweden has thus exhibited a somewhat pro-cyclical pattern, at least over the past 15 years or so. This pattern stands in sharp contrast to UI policies in some other countries, including Canada and the United States, where rising unemployment has triggered benefit extensions.

Figure 3. Unemployment (percent of labor force) and employment (percent of population 16-64), 2001:1 - 2003:1, seasonally adjusted data.

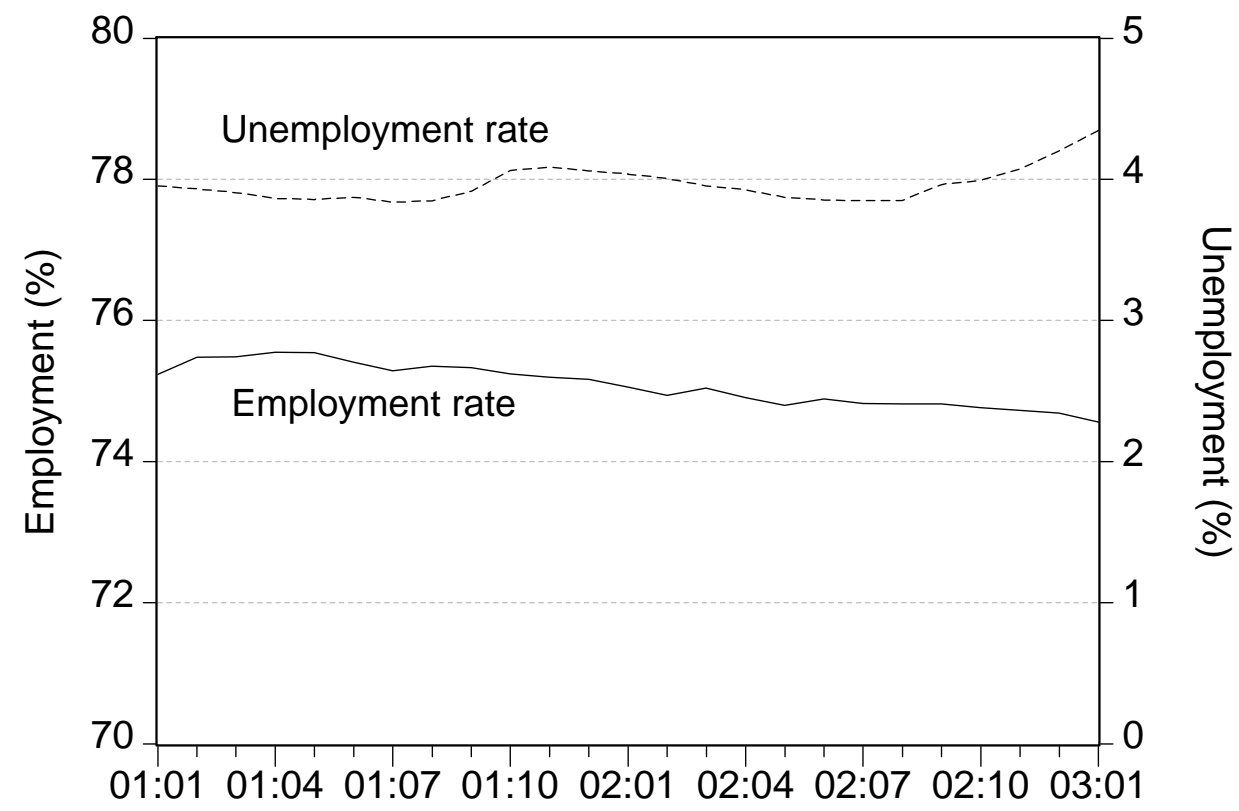

Source: Labor force surveys, Statistics Sweden. 
Figure 4. The number of vacancies, 2001:1 - 2003:01, seasonally adjusted data.

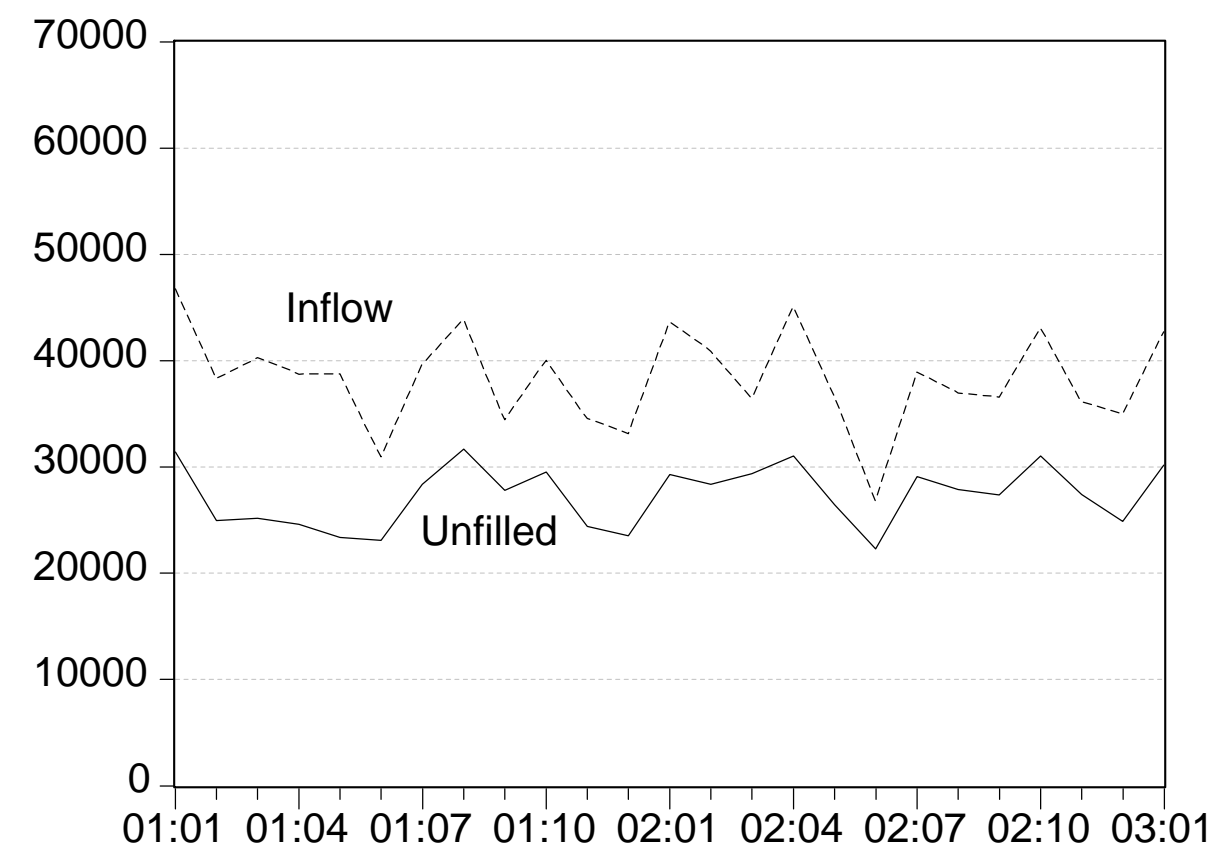

Source: The National Labor Market Board.

An evaluation of the effects of UI reforms on unemployment becomes difficult if the reforms are the results of rising unemployment. This problem of policy endogeneity may be particularly severe if identification relies on policy variations across regions (age groups) while at the same time this variation is caused by differential unemployment experiences across regions (age groups). If benefits are raised for older workers as a response to increasing labor market difficulties for this group, there is an obvious risk that the effect of benefits on unemployment duration is overstated; see the discussions in Card and Levine (2000) and Lalive and Zweimüller (2004). The Swedish UI reforms of 2001 and 2002 are not plagued by this sort of policy endogeneity, however. Although it can be argued that the benefit hikes were made possible by more favorable macroeconomic conditions, they were certainly not targeted at groups with above average unemployment (or above average increases in unemployment). To the extent that policy endogeneity is a problem, it is probably more likely that it leads to an understatement than an overstatement of the effect of benefit increases. However, the reforms of 2001 and 2002 took place under fairly stable macroeconomic conditions so this risk is probably small. 
Table 1. Unemployment and employment rates by age, gender and education.

\begin{tabular}{|c|c|c|c|c|c|c|}
\hline & \multicolumn{3}{|c|}{ Unemployment (\%) } & \multicolumn{3}{|c|}{ Employment (\%) } \\
\hline & 2000 & 2001 & 2002 & 2000 & 2001 & 2002 \\
\hline \multicolumn{7}{|l|}{ Age } \\
\hline $16-24$ & 8.1 & 8.0 & 8.6 & 46.1 & 47.9 & 46.5 \\
\hline $25-54$ & 4.0 & 3.3 & 3.3 & 83.8 & 84.6 & 84.2 \\
\hline \multicolumn{7}{|l|}{ Gender } \\
\hline Male & 5.0 & 4.3 & 4.4 & 76.1 & 77.0 & 76.3 \\
\hline Female & 4.3 & 3.6 & 3.6 & 72.2 & 73.5 & 73.4 \\
\hline \multicolumn{7}{|c|}{ Education level } \\
\hline 1 & 6.7 & 5.2 & 5.4 & 60.3 & 60.8 & 62.6 \\
\hline 2 & 7.8 & 6.6 & 6.2 & 58.6 & 58.8 & 57.5 \\
\hline 3 & 4.5 & 3.8 & 3.7 & 81.0 & 81.5 & 80.9 \\
\hline 4 & 5.1 & 4.6 & 4.7 & 76.1 & 77.7 & 77.9 \\
\hline 5 & 2.9 & 2.5 & 2.7 & 79.5 & 80.2 & 79.5 \\
\hline 6 & 2.0 & 2.0 & 2.4 & 90.2 & 88.1 & 87.9 \\
\hline
\end{tabular}

Note: Unemployment is measured relative the labor force and employment relative to population. Education level 1 is schooling less than 9 years whereas education level 6 is university education ( 3 years or more).

Source: Labor force surveys, Statistics Sweden.

\section{Theoretical Background}

Mortensen (1977) presented the seminal paper on the microeconomic effects of unemployment benefits. The key institutional ingredients of the analysis were (i) fixed duration of benefit payments, (ii) stochastic duration of employment spells, and (iii) an eligibility condition such that some work experience is required in order to qualify for UI. A worker facing a known wage offer distribution and aiming at maximizing lifetime utility will respond to the level of benefits as well as to the maximum length of benefit payments.

There are three principal predictions in Mortensen’s analysis: First, the exit rate from unemployment to employment increases over the spell of (insured) unemployment, a behavior 
resulting from a declining optimal reservation wage as the individual moves toward the date at which benefits expire. A second implication is that an increase in the benefit level makes it more attractive for individuals not qualified for UI to accept job offers and thereby become entitled to benefits in the future; this is the so-called entitlement effect. Finally, a rise in the benefit level will cause a newly unemployed and insured individual to increase his reservation wage but induce a decline in the reservation wage if the individual has come close to benefit exhaustion. The exit rate thus declines for a newly unemployed insured person but increases for individuals who are close to benefit exhaustion. The reason is that a higher benefit level increases the value of continued search as unemployed as well as the value of accepting a job offer. The value of higher benefits is negligible for persons close to benefit exhaustion; they are in fact in a situation very similar to individuals not qualified for UI.

The basic insights from Mortensen's seminal paper carry over to an analysis of recent Swedish reforms. The important feature in this regard is the introduction of a two-tiered benefit structure with a time limit of 20 weeks for supplementary benefits. Individuals who have just become unemployed have different incentives than those who have experienced 10 or 18 weeks of unemployment since the latter are closer to exhaustion of the supplementary benefit. Moreover, those who have survived as unemployed beyond 20 weeks should care about the level of supplementary benefits only to the extent that they recognize the possibility of becoming laid off when being employed in the future.

Consider Figure 5 that illustrates the hypothesized effects of the 2001 reform. Theory and evidence suggest that the job finding (or hazard) rate is increasing at an increasing rate as the worker approaches the date at which (supplementary) benefits expire. ${ }^{10}$ In the figure, as well as in subsequent estimations, we assume that this benefit-induced duration dependence can be approximated by an exponential function; hence we take the natural logarithm of the job hazard rate, $\ln h(t)$, as a linear function of time $(t)$ over the initial period. The pre-reform hazard rate is taken as reference case so the path illustrated in the figure describes deviations from the prereform path (i.e., the benefit system of 2000). The two-tiered benefit structure with a benefit drop at week 20 is analogous to a system with fixed benefit duration and benefit exhaustion at 
some known future date. The hazard will be rising over the first 20 weeks as workers become gradually more eager to get a job before they are transferred to the less generous second benefit tier.

Figure 5. Hypothetical effects of the 2001 reform.

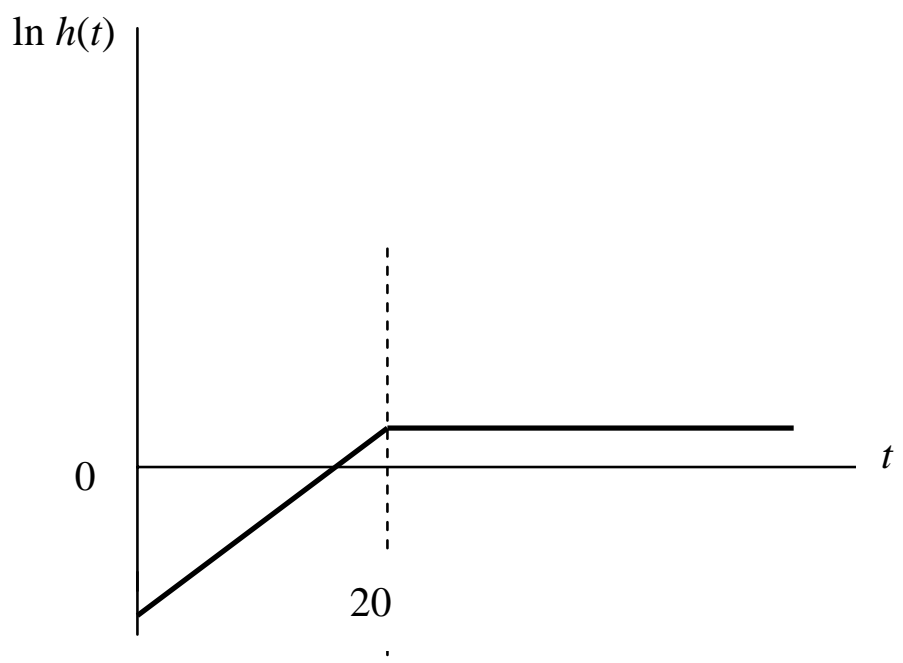

Figure 6. Hypothetical effects of the 2001-2002 reforms.

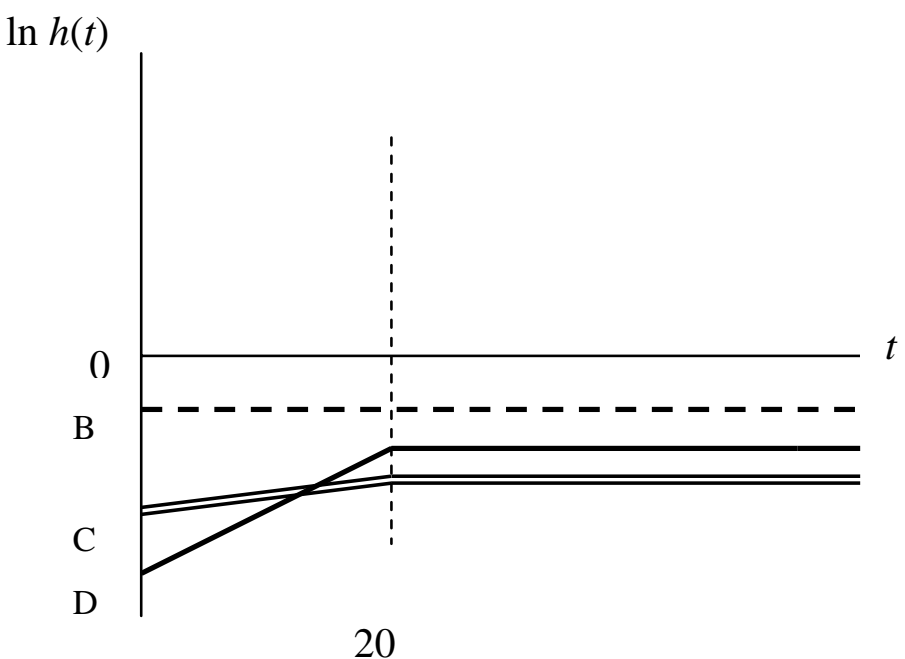

10 See Mortensen (1990) and Lancaster (1990), chapter 6, for theoretical expositions. Moffitt (1985), Meyer (1990) and Katz and Meyer (1990) provide evidence for the U.S. whereas Carling et al (1996) and Røed et al (2002) provide evidence for Sweden. 
Figure 5 also illustrates the entitlement effect. Unemployed workers who have exhausted the period with supplementary benefits realize that the only way to qualify for those benefits is to get a job; employment serves as an entry port to supplementary benefits. If the worker survives as unemployed beyond the first tier, the hazard beyond week 20 should be higher than in the pre-reform system without supplementary benefits. In a sense, the entitlement effect kicks in already before 20 weeks, as illustrated in the figure. The post-reform hazard overtakes the prereform hazard before the 20-week time limit is reached. A worker who has been unemployed for almost 20 weeks is approximately in the same situation as a worker who has entered the second benefit tier. The value of continued search as short-term unemployed is negligible and is dominated by the rise in the value of employment caused by the higher benefit level over the first 20 weeks. A worker who has come close to expiration of the initial supplementary benefits will therefore be more eager to escape unemployment than he would be in the pre-reform system with only one benefit tier.

Figure 5 illustrates a job finding path without discontinuous jumps at the point where supplementary benefits are exhausted. Mortensen (1977) shows that a jump can be part of the optimal strategy under some assumptions about the worker's utility function. If income and leisure are Edgeworth complements (substitutes), the optimal plan involves an upward (downward) jump of the exit rate at the exhaustion point. We ignore jumps in the following discussion, noting that continuity at the exhaustion point is implied by a utility function where the marginal utility of leisure is independent of income. In the empirical analysis, however, we will allow for jumps at the exhaustion point.

By looking at Figure 2, it is clear that the 2001 reform should have a weaker impact, on average, on the B group than on workers in the $\mathrm{C}$ and $\mathrm{D}$ categories. The rise in supplementary daily benefits varies from zero to $100 \mathrm{SEK}$ - or from zero to 17.2 percent - for B workers, depending on their pre-unemployment wage. In terms of Figure 5, the exact position of the hazard depends on the dose of the treatment, where the dose is determined by the previous wage.

The 2002 reform is more complex since it involved increases in benefit ceilings throughout the benefit period, albeit with a bigger increase for the second tier (+100 SEK) than for the first 
one (+50 SEK). Figure 6 illustrates three possible paths for the relative hazards, i.e., the postreform hazards relative to a reference hazard associated with the UI system prevailing in 2000; these hazards thus incorporate the effects of both the 2001 and the 2002 reforms. The three hazards correspond to the three treatment groups, i.e., B, C and D.

For B workers, the 2002 reform involves a re-establishment of a flat benefit profile (see Figure 2). The only change takes place beyond 20 weeks of unemployment and the benefit hike varies between zero and 100 SEK depending on the previous wage. The horizontal B line in Figure 6 illustrates one possible post-2002 hazard for a B worker; recall that the treatment dose varies within the B group and thus also the position of the hazard line.

For C and D workers, the 2002 reform retains the two-tiered benefit structure. The benefit drop after week 20 is however much smaller in the new system, varying between zero (for $\mathrm{C}$ workers with wages just above $850 \mathrm{SEK}$ ) to 50 SEK (for workers in the D category). This flattening of the benefit profile should produce a flattening of the associated hazard profiles. The two-tiered benefit structure implies that entitlement-type effects may be present: workers unemployed beyond week 20 realize that employment qualifies for the more generous first tier and may respond accordingly. However, the fact that the 2002 reform entailed benefit hikes also in the second tier means that the positive entitlement effect is counteracted by the usual adverse incentive effect. Since the second-tier benefit hike was substantial (100 SEK or 17.2 percent), there is a presumption that the 2002 reform has caused downward shifts of the $\mathrm{C}$ and D hazards throughout the unemployment spell, as illustrated in Figure 6.

As drawn in Figure 6, the $C$ and $D$ hazards cross before 20 weeks; the $C$ exit rate is initially higher but subsequently lower than the $\mathrm{D}$ rate. This possible pattern could be the result of a powerful entitlement effect. The long-term unemployed D workers have more to gain by getting reemployed (in terms of supplementary benefits), and should therefore be more keen to exit unemployment than long-term unemployed $C$ workers. In the special case where entitlement effects are absent, the post-20 exit rates should be identical for C and D workers. The reason is that only benefits during the current unemployment spell matters when the layoff consequences of future employment are ignored. 
Recall that the 2002 reform entails “dose heterogeneity” within the C group for the first 20 weeks. For workers close to the B region in terms of previous wages, the post 2002 hazard should be close to flat. For workers close to the D region, the corresponding hazard should be close to the hazard for the D group. Figure 6 illustrates a possible hazard path for a typical C worker.

We have discussed entitlement effects as if job finding automatically qualifies for supplementary benefits in case of a future reentry into unemployment. This is clearly a simplification of the institutional rules pertaining to Swedish UI. Immediate entitlement to supplementary benefits does not apply unless the working conditions are met (at least 420 hours of work over the recent 12-month period). It is clear, however, that entitlement incentives are always present: the quicker the unemployed worker returns to employment, the closer he is to the fulfillment of the working conditions that qualify for benefits.

The analysis of the two-tiered benefit system has also ignored the question whether the second tier involves a fixed or unlimited duration. As already noted, the Swedish system has a soft time limit of 60 weeks; there is a possibility of renewal under some conditions as well as a possibility of entering a labor market program with the same level of compensation as during insured unemployment. All in all, it is unclear how stringent the time limit on UI payments really is. Our theoretical discussion of qualitative effects does not hinge on this, however; the evolutions of the post-reform hazard functions are measured relative to a reference case with arbitrary duration pattern. The empirical analysis will allow flexible functional forms for the baseline hazard.

The discussion so far has considered individuals who are exposed to different benefit regimes from the start of their unemployment spells and ignored anticipatory behavior, i.e., the possibility that individuals learn about and respond to the reforms before those actually are implemented. The reforms under consideration were announced relatively close to the actual implementations, the 2001 reform in late April 2001 (eight weeks in advance) and the 2002 reform in late May 2002. 


\section{The Data}

One main data source is HÄNDEL, a database maintained by the National Labor Market Board (AMS) containing all registered spells at the labor market offices. ${ }^{11}$ The propensity to register at the offices is very high among unemployed individuals and in particular among those who are entitled to unemployment benefits. ${ }^{12}$ The spell data contain detailed information on labor market transitions. Moreover, a set of background characteristics is stored for all registered individuals. The second main database is ASTAT, which contains detailed information on benefit receipts and pre-unemployment wages. ASTAT is maintained by AMS but the data are provided by the UI funds.

ASTAT and HÄNDEL have been merged with a number of restrictions imposed. The individual should appear as newly registered between January 1, 2000 and October 27, 2002;13 should have at least one period of benefit receipt since January 1, 1999; and should have been full-time employed prior to the unemployment spell. From this set of unemployment spells we select those that begin after February 5, 2001. The observation window is closed in January 13 2003. We exclude disabled workers as well as workers over age 54. Moreover, we retained only unemployment spells where the individual is "available for work" (ready to take a job immediately). In order to avoid comparisons between workers with hugely different market wages, we have as a requirement for sample inclusion set a floor as well as a cap on preunemployment wages. The floor is set at 600 SEK per day (13 200 SEK per month) and the cap at 1100 SEK (24 200 SEK).

We measure unemployment in weeks and set the first week of benefit receipt as the start of the unemployment spell. The destination state of interest, i.e., employment, can be defined in several ways. Our preferred definition corresponds roughly to the definition in the labor force surveys. The end of the spell is determined by information in HÄNDEL. Sickness or other events may cause interruption of benefit receipt but such an episode constitutes an end of the unemployment spell only to the extent that HÄNDEL registers a change of state. We define

\footnotetext{
11 The construction of the data set is described in more detail in an appendix that is available on request. 12 A study by Statistics Sweden (1993) shows that more than 90 percent of those who were reported as unemployed in the labor force surveys in August - October 1992 also registered at the public employment offices.

${ }^{13}$ By newly registered we mean that the person has not been registered during the preceding 30 days.
} 
unemployment spells so that very brief intervening employment spells, lasting shorter than ten days, are counted as part of the unemployment spell. Although the inflow pertains to "open” unemployment, we treat subsequent participation in active labor market programs as part of the unemployment spell. Spells extending beyond week 60 are treated as censored.

Information on local unemployment is merged with the data set so as to capture local labor market conditions. We use current and the first difference of monthly values of municipal unemployment rates where unemployment is defined inclusive of part-time unemployed as well as participants in active labor market programs. ${ }^{14}$

Some descriptive information about the data is given in Tables 2, 3 and 4. The fact that we select control and treatment groups on the basis of pre-unemployment wages implies some predictable differences between the groups. As is seen from Table 2, the treated individuals tend to be somewhat older, better educated and more experienced. There are virtually no groupdifferences concerning local labor market conditions, however. Notice from Table 3 that only 18 percent of the males (33 percent of the females) reached the statutory replacement rate of 80 percent before the reforms were put into effect. The picture is very different in July 2002, i.e., after the two reforms. 65 percent of the males (75 percent of the females) are now compensated at 80 percent for the first 20 weeks. Clearly, the UI reforms had a massive impact on the distribution of replacement rates. Around one third of the spells continue beyond 20 weeks, as is seen from Table 4. The majority of the spells end by a transition to employment. The expected time to job finding is around 30 weeks.

\footnotetext{
14 The variable is defined as $u=(U+A L M P) /(U+A L M P+E)$, where $U$ is total open unemployment including part-time unemployed, $A L M P$ the number of participants in active labor market programs and $E$ the number of employed workers. This extended definition of unemployment explains why average unemployment rates shown in Table 2 are about twice as high as conventional measures of open unemployment.
} 
Table 2. Sample characteristics by treatment and control spells (means).

\begin{tabular}{|c|c|c|c|c|c|c|c|c|}
\hline \multirow[b]{2}{*}{ Parameter } & \multicolumn{4}{|c|}{ Men } & \multicolumn{4}{|c|}{ Women } \\
\hline & A & $\mathrm{B}$ & $\mathrm{C}$ & $\mathrm{D}$ & A & B & $\mathrm{C}$ & $\mathrm{D}$ \\
\hline \multicolumn{9}{|l|}{ Demographics } \\
\hline Age & 30.0 & 33.0 & 34.4 & 35.6 & 31.5 & 34.1 & 34.7 & 35.6 \\
\hline Swedish citizenship & .890 & .929 & .948 & .959 & .909 & .938 & .952 & .952 \\
\hline Other Nordic countries & .011 & .018 & .018 & .020 & .023 & .022 & .020 & .024 \\
\hline Other European countries & .038 & .028 & .021 & .013 & .032 & .023 & .020 & .017 \\
\hline Non-European countries & .061 & .025 & .012 & .008 & .036 & .017 & .008 & .007 \\
\hline \multicolumn{9}{|l|}{$\begin{array}{l}\text { Human capital and working time } \\
\text { flexibility }\end{array}$} \\
\hline Elementary school, $<9$ years & .081 & .086 & .075 & .073 & .067 & .047 & .026 & .025 \\
\hline Elementary school & .139 & .143 & .138 & .122 & .108 & .096 & .078 & .060 \\
\hline High school (ref.) & .594 & .551 & .546 & .534 & .565 & .455 & .369 & .307 \\
\hline University, $<2$ years & .067 & .070 & .072 & .076 & .092 & .098 & .103 & .126 \\
\hline University & .118 & .143 & .156 & .182 & .167 & .294 & .391 & .454 \\
\hline University, graduate level & .002 & .008 & .016 & .012 & .001 & .010 & .033 & .028 \\
\hline $\begin{array}{l}\text { Work experience in } \\
\text { preferred occupation }\end{array}$ & .753 & .804 & .838 & .881 & .766 & .793 & .809 & .840 \\
\hline $\begin{array}{l}\text { wage prior to unemployment } \\
\text { (SEK/day) }\end{array}$ & 676 & 789 & 881 & 989 & 671 & 782 & 880 & 993 \\
\hline Willing to take part-time job & .356 & .307 & .291 & .273 & .391 & .367 & .352 & .356 \\
\hline \multicolumn{9}{|l|}{ Local labor market } \\
\hline Unemployment rate & 11.7 & 11.9 & 11.9 & 11.8 & 11.2 & 11.0 & 10.4 & 9.8 \\
\hline \multicolumn{9}{|l|}{$\begin{array}{l}\text { Participation in active labor market } \\
\text { programs }\end{array}$} \\
\hline $\begin{array}{l}\text { Fraction of total number of } \\
\text { unemployment weeks }\end{array}$ & .142 & .133 & .105 & .084 & .114 & .105 & .081 & .070 \\
\hline \multicolumn{9}{|l|}{ Previous unemployment } \\
\hline No previous spell (ref.) & .355 & .450 & .491 & .495 & .443 & .535 & .572 & .590 \\
\hline One previous spell & .332 & .296 & .265 & .245 & .312 & .284 & .265 & .247 \\
\hline More than one previous spells & .313 & .254 & .244 & .260 & .245 & .182 & .163 & .127 \\
\hline Days of unemployment & 243 & 233 & 224 & 212 & 186 & 177 & 173 & 163 \\
\hline \multicolumn{9}{|l|}{ Period of registration } \\
\hline 01 Feb 01- 30 June 01 & .208 & .185 & .185 & .167 & .200 & .170 & .147 & .128 \\
\hline 01 July 01-29 June 02 & .627 & .628 & .628 & .635 & .601 & .608 & .588 & .600 \\
\hline 30 June 02 & .165 & .187 & .187 & .198 & .199 & .222 & .265 & .272 \\
\hline \# spells & 6536 & 13918 & 6761 & 10535 & 7967 & 9654 & 3098 & 3708 \\
\hline
\end{tabular}

Notes: Previous unemployment refers to open unemployment or program participation during three years preceding the spell. Days of previous unemployment is given for observations with at least one previous spell. 
Table 3a. Replacement rates: males.

\begin{tabular}{|c|c|c|c|c|c|}
\hline & \multirow{2}{*}{$\begin{array}{c}\text { Before July } \\
2001 \\
\end{array}$} & \multicolumn{2}{|c|}{ July 2001 - June 2002} & \multicolumn{2}{|c|}{ From July 2002} \\
\hline & & $\leq 100$ days & $>100$ days & $\leq 100$ days & $>100$ days \\
\hline 0.80 & .180 & .490 & .177 & .650 & .484 \\
\hline$[0.775,0.80)$ & .010 & .118 & .096 & .110 & .128 \\
\hline$[0.75,0.775)$ & .091 & .078 & .091 & .066 & .072 \\
\hline$[0.725,0.75)$ & .087 & .083 & .091 & .057 & .087 \\
\hline$[0.70,0.725)$ & .092 & .075 & .086 & .046 & .064 \\
\hline$[0.65,0.70)$ & .183 & .106 & .173 & .071 & .113 \\
\hline$[0.60,0.65)$ & .149 & .050 & .146 & .000 & .051 \\
\hline$<0.60$ & .119 & .000 & .140 & .000 & .000 \\
\hline
\end{tabular}

Table 3b. Replacement rates: females.

\begin{tabular}{|c|c|c|c|c|c|}
\hline & \multirow{2}{*}{$\begin{array}{c}\text { Before July } \\
2001 \\
\end{array}$} & \multicolumn{2}{|c|}{ July 2001 - June 2002} & \multicolumn{2}{|c|}{ From July 2002} \\
\hline & & $\leq 100$ days & $>100$ days & $\leq 100$ days & $>100$ days \\
\hline 0.80 & .330 & .645 & .277 & .755 & .570 \\
\hline$[0.775,0.80)$ & .150 & .132 & .143 & .101 & .144 \\
\hline$[0.75,0.775)$ & .101 & .044 & .097 & .035 & .057 \\
\hline$[0.725,0.75)$ & .078 & .051 & .079 & .037 & .063 \\
\hline$[0.70,0.725)$ & .069 & .033 & .082 & .031 & .046 \\
\hline$[0.65,0.70)$ & .126 & .063 & .140 & .041 & .086 \\
\hline$[0.60,0.65)$ & .075 & .027 & .091 & .000 & .034 \\
\hline$<0.60$ & .070 & .000 & .091 & .000 & .000 \\
\hline
\end{tabular}

Notes: Replacement rates for job seekers receiving their first week of benefits are given in the columns labeled "before July 2001” and “ $\leq 100$ days”. Replacement rates for job seekers receiving their $21^{\text {st }}$ week of benefits are given in the columns labeled “ >100 days”. 
Table 4. Spell characteristics.

Males $\quad$ Females

\begin{tabular}{lll}
\hline Mean length of spell (weeks) & 18.7 & 16.9 \\
Expected time to employment (weeks) & 29.3 & 32.1 \\
\hline
\end{tabular}

Proportion of spells lasting more than:

$\begin{array}{lll}4 \text { weeks } & 0.823 & 0.793 \\ 8 \text { weeks } & 0.677 & 0.638 \\ 13 \text { weeks } & 0.512 & 0.462 \\ 20 \text { weeks } & 0.342 & 0.302 \\ 26 \text { weeks } & 0.252 & 0.214 \\ 39 \text { weeks } & 0.124 & 0.100 \\ 52 \text { weeks } & 0.068 & 0.049\end{array}$

\section{Number of spells ending in:}

$\begin{array}{lll}\text { Employment } & 23701 & 14475 \\ \text { Other destinations } & 5978 & 5571 \\ \text { Censored } & 8071 & 4381 \\ \text { \# spells } & 37750 & 24427 \\ \begin{array}{l}\text { Proportion of jobseekers with } \\ \text { multiple spells }\end{array} & 0.0029 & 0.0015\end{array}$

Notes: Censored spells are spells still in progress when the observation window is closed, or spells in progress but with $R=0$, where $R$ is remaining time on benefits. Mean length of spell is the average duration of the spells irrespective of whether they end by employment or otherwise, including censored spells. Expected time to employment is calculated by recognizing censoring and assuming a constant hazard after the $60^{\text {th }}$ week. These calculations make use of estimated hazard models without covariates but with flexible weekly duration pattern.

\section{Empirical Analysis}

\section{$\underline{5.1 \text { Empirical Models }}$}

To estimate the effects of the reforms we make use of difference-in-differences specifications where the evolution of the hazard rates for control and treatment groups are compared before and after the reform dates. The models are estimated on weekly data. The job finding 
probability is related to time-invariant as well as time varying variables pertaining to the individual and the labor market. Let $X$ be a vector of variables, including time-varying covariates, and let $\Omega$ be the associated vector of parameters. We estimate a discrete-time hazard model of the form:

$$
h(t)=1-\exp [-\exp (X \Omega+\mu(t))]
$$

where $\mu(t)$ captures the flexible baseline hazard. To facilitate interpretation we rewrite the model as: 15

$$
\ln h(t)=X^{*}(t) \Omega^{*}
$$

The model given by (2) represents the reference hazard used as the benchmark for assessing the effects of UI reforms in 2001 and 2002. To this benchmark we add an extensive set of covariates as well as variables intended to capture the UI reforms. The latter are as follows:

a. Dummies for the three treatment groups: $T^{B}, T^{C}$ and $T^{D}$.

b. Time dummies for reforms: $D^{01}$ for weeks beyond July 1,2001 , and $D^{02}$ for weeks beyond July 1, 2002.

c. Dummies for duration status: $U^{S}$ for short-term unemployed, i.e., unemployment spells shorter than or equal to 20 weeks. The complementary dummy $1-U^{S}$ captures spells beyond 20 weeks (long-term unemployment).

d. A variable capturing remaining time on benefits, assuming 60 weeks as the maximum number of insured weeks. Let $R$ denote remaining time of entitlement to benefits. The variable $(60-R) U^{S}$ starts at zero for workers that enter the unemployment spell at the beginning of a benefit period with 60 remaining weeks. The maximum value of the variable

\footnotetext{
15 By taking the logs of (1) one obtains $\ln [-\ln (1-h(t))]=X \Omega+\mu(t)=X^{*}(t) \Omega^{*}$, where the left-hand side is approximately equal to $\ln h(t)$. The parameter vector $\Omega$ is identical to that of a continuous-time proportional hazards model if the covariates and the hazards are constant within each week. Each discrete time observation is treated as a separate observation in our data set. For each observation (week), the response is dichotomous (job
} 
is 20. The role of this variable is to allow for slope-changes of the hazard as a result of the reforms (cf. figures 5 and 6).

Consider first the 2001 reform and imagine, for expositional simplicity, that there is only one treatment group, B. We allow the hazard to increase over the first 20 weeks of unemployment. For simplicity the change in the log hazard rate is taken to be linear, recalling that theory and evidence suggest that the hazard rate should be increasing at an increasing rate up to the benefit exhaustion point. A general specification is as follows:

$$
\ln h(t)=X^{*}(t) \Omega^{*}+\left[\alpha_{0}+\alpha_{1} U^{S}(60-R)+\alpha_{2}\left(1-U^{S}\right) 20\right] T^{B} D^{01}
$$

The effect of the 2001 reform on the hazard at $R=60$, i.e., the start of the spell, is captured by $\alpha_{0}$. The effect of approaching the 20-week limit is captured by $\alpha_{1}$. From theory we expect $\alpha_{0}<0$ and $\alpha_{1}>0$ (cf. Figure 5). The general specification involves several special cases:

(i) Naïve specification: $\alpha_{0}<0, \alpha_{1}=\alpha_{2}=0$, implying that the reform has caused a permanent downward shift of the hazard; the shift being of the same magnitude before as well as after 20 weeks.

(ii) Continuity of the hazard (no jump) at week 20: $\alpha_{1}=\alpha_{2}$.

(iii) No entitlement effect: $\alpha_{0}+\alpha_{1} 20=0$.

If the continuity restriction is imposed we obtain:

$$
\ln h(t)=X^{*}(t) \Omega^{*}+\left[\alpha_{0}+\alpha_{1}\left(U^{S}(60-R)+\left(1-U^{S}\right) 20\right)\right] T^{B} D^{01}
$$

With three treatment groups we can write a general specification for the 2001 reform as:

finding or not). The model is estimated by means of the logistic procedure in SAS, using the complementary loglog link function. 


$$
\ln h(t)=X^{*}(t) \Omega^{*}+\left[\sum_{j} \alpha_{0}^{j}+\sum_{j} \alpha_{1}^{j} U^{S}(60-R)+\sum_{j} \alpha_{2}^{j}\left(1-U^{S}\right) 20\right] T^{j} D^{01}
$$

for $j=\mathrm{B}, \mathrm{C}$ and $\mathrm{D}$. There are thus 9 parameters to estimate in the most general specification. The 2002 reform is incorporated by a straightforward extension of (5) and include 9 additional parameters, i.e., $\beta_{1}^{j}, \beta_{2}^{j}$ and $\beta_{2}^{j}$ for $j=\mathrm{B}, \mathrm{C}$ and $\mathrm{D}$ :

$$
\ln h(t)=X^{*}(t) \Omega^{*}+\left[\sum_{j} \alpha_{0}^{j}+\sum_{j} \alpha_{1}^{j} U^{S}(60-R)+\sum_{j} \alpha_{2}^{j}\left(1-U^{S}\right) 20\right] T^{j} D^{01}
$$

(6)

$$
+\left[\sum_{j} \beta_{0}^{j}+\sum_{j} \beta_{1}^{j} U^{S}(60-R)+\sum_{j} \beta_{2}^{j}\left(1-U^{S}\right) 20\right] T^{j} D^{02}
$$

To get the total effect of the 2001 and 2002 reforms we add the estimated parameters of interest. For example, the post 2002 hazard for category B takes the form:

$$
\ln h(t)=X^{*}(t) \Omega^{*}+\left[\alpha_{0}^{B}+\alpha_{1}^{B} U^{S}(60-R)+\alpha_{2}^{B}\left(1-U^{S}\right) 20\right] T^{B} D^{01}
$$

$$
+\left[\beta_{0}^{B}+\beta_{1}^{B} U^{S}(60-R)+\beta_{2}^{B}\left(1-U^{S}\right) 20\right] T^{B} D^{02}
$$

which can be written as

(8) $\ln h(t)=X^{*}(t) \Omega^{*}+\alpha_{0}^{B}+\beta_{0}^{B}+\left(\alpha_{1}^{B}+\beta_{1}^{B}\right) U^{S}(60-R)+\left(\alpha_{2}^{B}+\beta_{2}^{B}\right)\left(1-U^{S}\right) 20$

since $T^{B} D^{01}=T^{B} D^{02}=1$ for the B group when both reforms have kicked in.

There are in general both cross-sectional and time series variations in $R$ that contribute to identification of the effect on job finding of approaching the 20-week limit. The cross-sectional variation arises because individuals enter the observation window with different values of $R$, where the differences depend on their recent unemployment history. It can be argued that this variation may capture unobserved individual heterogeneity. To remove this heterogeneity one 
could restrict the analysis to spells that begin with exactly 60 remaining weeks of benefit receipt. This reduces the sample by about 50 percent. We have followed the latter approach. Moreover $R$ is defined so that it is not affected by realized benefit receipt during the unemployment spell. At the start of each spell, $R$ is given by actual remaining time on benefits. From this point and onwards, $R$ is represented by a linear (descending) trend.

We use a large number of covariates to control for individual heterogeneity. This set of variables includes age and age squared, the logarithm of the pre-unemployment wage, five dummies for level of education, one dummy for previous work experience, a dummy that informs about willingness to accept part-time jobs, eight dummies for occupation, three dummies for foreign citizenship, 20 dummies for region (counties), time effects captured by 7 dummies for quarter, 12 seasonal dummies (four-week periods) for time of outflow, and 12 seasonal dummies (four-week periods) for time of inflow into unemployment. Three controls for participation in active labor market programs during an ongoing spell are also included. In addition we include controls for the individuals' unemployment experiences prior to the unemployment spells under examination, viz. dummies for the number of unemployment spells over the past three years, and the total time spent in unemployment over the those years. Local labor market conditions are represented by time-varying municipal unemployment rates pertaining to the current as well as the previous month. The baseline hazard is allowed to vary week by week.

\section{$\underline{5.2 \text { Empirical Results }}$}

Estimation results for the 18 policy parameters are set out in Table 5. Other results are given in an appendix. To aid in interpreting the estimates, we show in Figure 7 the implied (log) hazard profiles (relative to the pre-reform profile) after the 2001 reform and in Figure 8 the implied profile after both reforms have kicked in. The strikingly different profiles for men and women stand out. The "big picture" for men is a substantial downward shift, i.e., a substantial fall in job finding. The profiles for women are close to mirror images of men's profiles: the benefit hikes appear to have produced increases in job finding for all treatment groups.

Looking at the estimated profiles for men, and focusing on weeks beyond 20, we observe a lower rate of job finding after the combined 2001/2002 reform than after the 2001 reform. This 
is as expected, remembering that the 2002 reform entailed a rise in regular benefits beyond week 20. For men, the additional fall in long-term job finding due to the 2002 reform is estimated to be around 5 to 10 percent, depending on treatment group. The overall picture for women is more or less the opposite of what we observe for men. The female hazards beyond week 20 are higher after the 2002 reform than before the reform. This is at odds with what we would expect from theory.

Table 5. Estimation results for the 18 reform parameters.

\begin{tabular}{|c|c|c|c|c|c|c|}
\hline \multirow[b]{2}{*}{ Parameter } & \multicolumn{3}{|c|}{ Men } & \multicolumn{3}{|c|}{ Women } \\
\hline & Estimate & se & $p$-value & Estimate & se & $p$-value \\
\hline$\alpha_{0}^{B}$ & -.0515 & .0797 & .5181 & .0428 & .0876 & .6251 \\
\hline$\alpha_{1}^{B}$ & -.0104 & .00439 & .0183 & .00163 & .00485 & .7373 \\
\hline$\alpha_{2}^{B}$ & -.00517 & .00312 & .0981 & .00311 & .00338 & .3574 \\
\hline$\alpha_{0}^{C}$ & -.1157 & .0904 & .2003 & -.11 & .1349 & .415 \\
\hline$\alpha_{1}^{C}$ & -.0081 & .00519 & .1183 & .0197 & .00745 & .0081 \\
\hline$\alpha_{2}^{C}$ & -.00885 & .00376 & .0186 & .013 & .00525 & .0134 \\
\hline$\alpha_{0}^{D}$ & -.00167 & .0851 & .9843 & -.0443 & .1362 & .745 \\
\hline$\alpha_{1}^{D}$ & -.0117 & .00454 & .01 & .0197 & .00693 & .0046 \\
\hline$\alpha_{2}^{D}$ & -.0106 & .00336 & .0017 & .0128 & .00491 & .0091 \\
\hline$\beta_{0}^{B}$ & .1492 & .0694 & .0314 & .0323 & .07 & .6449 \\
\hline$\beta_{1}^{B}$ & -.00752 & .00575 & .1911 & .000997 & .00654 & .8788 \\
\hline$\beta_{2}^{B}$ & -.0122 & .00378 & .0013 & .00132 & .0044 & .7645 \\
\hline$\beta_{0}^{C}$ & .0215 & .0887 & .8088 & .3191 & .111 & .0041 \\
\hline$\beta_{1}^{C}$ & -.00756 & .00797 & .3426 & -.0312 & .0112 & .0052 \\
\hline$\beta_{2}^{C}$ & -.00607 & .00529 & 2514 & -.0113 & .00732 & . 1231 \\
\hline$\beta_{0}^{D}$ & .0478 & .0718 & .5059 & .1414 & .1044 & .1754 \\
\hline$\beta_{1}^{D}$ & -.00827 & .00615 & .1788 & -.0124 & .01 & .2162 \\
\hline$\beta_{2}^{D}$ & -.00551 & .00416 & .1853 & -.00192 & .00676 & .7759 \\
\hline$-2 \log L$ & & 373.06 & & 12 & 48.81 & \\
\hline \# weeks & & 15009 & & & 819 & \\
\hline
\end{tabular}

Notes: Other variables are those described in the text. Table A1 in the appendix presents additional results. 
Figure 7. Effects of the 2001 reform on male (m) and female (f) job finding.

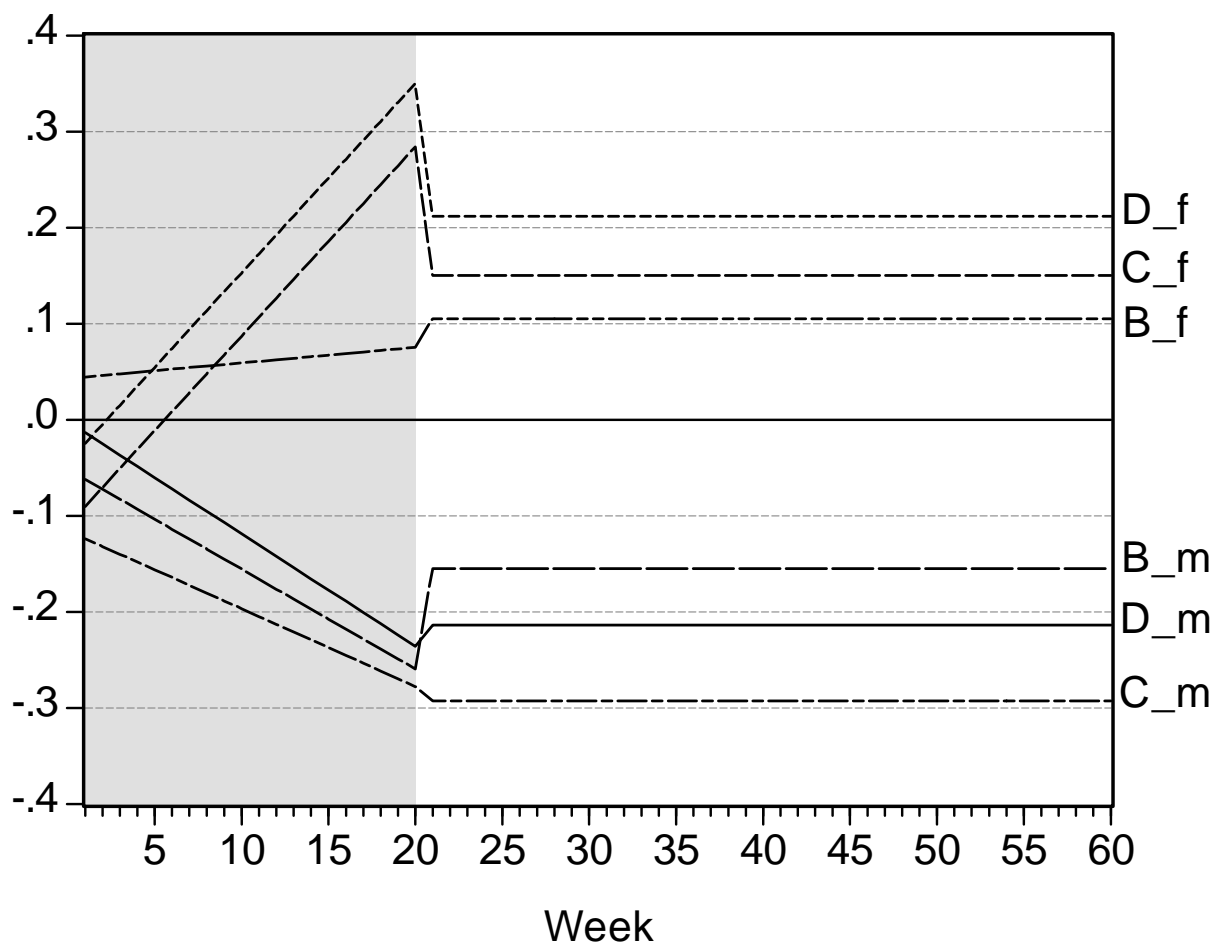

Figure 8. Effects of the 2001/2002 reforms on male (m) and female (f) job finding.

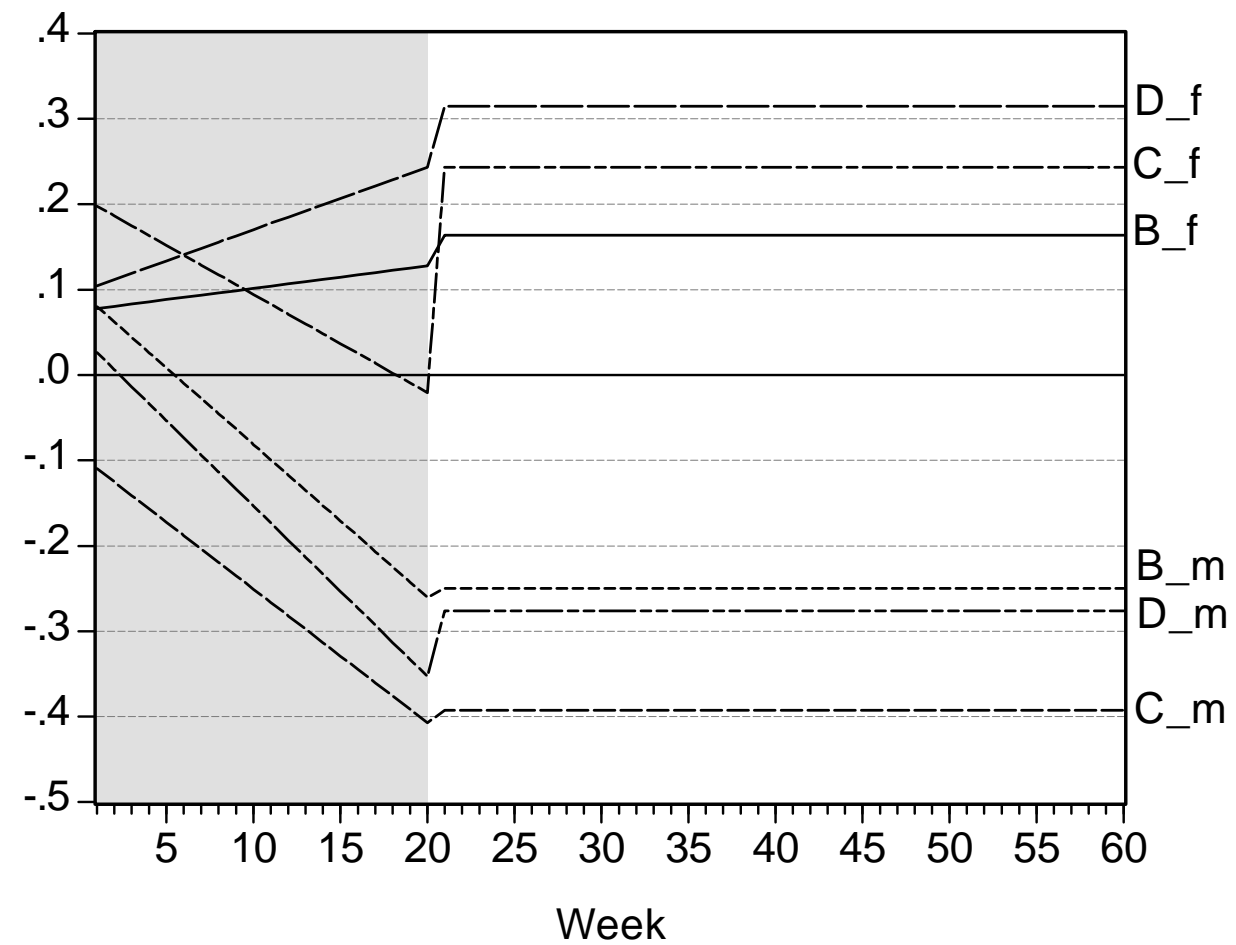


The negative effects on male job finding are more precisely estimated than the positive effects on female job finding. Consider the combined effect of the two reforms after week 20, i.e., the period when supplementary benefits have been exhausted. Table 6 presents point estimates for the hazards as well as $p$-values for zero effects. The adverse effect on male job finding is highly significant ( $p=.003$ or less) whereas the positive effect on female job finding is marginally significant ( $p=.08$ or less).

We have also calculated the implied change in the expected duration of unemployment resulting from the UI reforms. We compute the expected time to employment before and after the reforms for the control and treatment groups (see Table 7). For men, the implied increase in duration ranges from 3.6 weeks (group B) to 7 weeks (group C). For women, the implied reductions are substantial, ranging between 4 and 9 weeks. The confidence intervals reveal, however, that the estimated changes in duration are often statistically insignificant at conventional levels. ${ }^{16}$ For males, the increase for the $\mathrm{C}$ group is significant at the 5 percent level, whereas the increase for the $\mathrm{D}$ group is significant the 10 percent level. The overall increase for the male treatment groups is significant at the 10 percent level. For females, statistical significance obtains for the $\mathrm{D}$ group at the 10 percent level and also for the treatment groups taken together (at 10 percent). The overall change in expected duration, taking males and females together, is not statistically significant.

\footnotetext{
${ }^{16}$ Confidence intervals were based on bootstrapping. In the bootstrap procedure we based our calculation on the asymptotic distribution of the reform parameters. The distribution is multivariate normal with means assumed to be the estimates of the parameters and a covariance matrix assumed to be the estimated covariance matrix of the reform parameters. We draw pseudo-random numbers from this multivariate distribution as bootstrapped reform parameters and repeated the calculation of the expected duration as described above. The procedure was repeated 799 times. In this manner a distribution of expected durations was obtained. The 95 percent confidence interval was defined by the $2.5^{\text {th }}$ and $97.5^{\text {th }}$ percentiles of the distribution.
} 
Table 6. Estimated effects of both reforms on job finding after week 20.

\begin{tabular}{c|rr|rc}
\hline & \multicolumn{2}{c}{ Men } & \multicolumn{2}{c}{ Women } \\
\hline $\begin{array}{l}\text { Treatment } \\
\text { group }\end{array}$ & Estimate & $p$-value & Estimate & $p$-value \\
\hline B & -.249 & .003 & .164 & .083 \\
C & -.393 & $<.0001$ & .243 & .080 \\
D & -.275 & .002 & .315 & .023 \\
\end{tabular}

Notes: The point estimates are given as $E^{j} \equiv \alpha_{0}^{j}+20 \alpha_{2}^{j}+\beta_{0}^{j}+20 \beta_{2}^{j}$ for $j=\mathrm{B}, \mathrm{C}$, D. The null is $E^{j}=0$.

Table 7. The effect of the UI reforms on the expected duration of unemployment.

\begin{tabular}{|c|c|c|c|c|}
\hline & $\begin{array}{c}\text { Before } 1 \text { July } \\
2001 \\
\end{array}$ & $\begin{array}{c}\text { After } 1 \text { July } \\
2002 \\
\end{array}$ & $\begin{array}{c}\text { Change in } \\
\text { weeks }\end{array}$ & $\begin{array}{c}\text { Change in } \\
\text { percent }\end{array}$ \\
\hline Men & & & & \\
\hline A & 28.2 & 28.2 & 0 & 0 \\
\hline B & 22.3 & $\begin{array}{c}25.9 \\
(20.2-32.7)[21.3-31.9]\end{array}$ & 3.6 & 16.3 \\
\hline C & 18.1 & $\begin{array}{c}25.1 \\
(18.6-32.7)[19.4-31.8]\end{array}$ & 7.0 & 38.7 \\
\hline $\mathrm{D}$ & 18.2 & $\begin{array}{c}22.3 \\
(17.7-28.2)[18.6-27.3]\end{array}$ & 4.1 & 22.5 \\
\hline $\mathrm{B}, \mathrm{C}$ and $\mathrm{D}$ & 19.8 & $\begin{array}{c}24.4 \\
(19.5-30.6)[20.3-29.5]\end{array}$ & 4.6 & 23.0 \\
\hline \multicolumn{5}{|l|}{ Women } \\
\hline A & 28.1 & 28.1 & 0 & 0 \\
\hline B & 32.6 & $\begin{array}{c}28.4 \\
(22.9-35.2)[23.9-33.8]\end{array}$ & -4.3 & -13.0 \\
\hline $\mathrm{C}$ & 36.3 & $\begin{array}{c}30.0 \\
(23.2-40.3)[24.2-38.2]\end{array}$ & -6.3 & -17.4 \\
\hline $\mathrm{D}$ & 41.1 & $\begin{array}{c}32.0 \\
(24.7-41.7)[25.7-39.7]\end{array}$ & -9.1 & -22.1 \\
\hline $\mathrm{B}, \mathrm{C}$ and $\mathrm{D}$ & 35.1 & $\begin{array}{c}29.5 \\
(24.4-35.5)[25.2-34.6]\end{array}$ & -5.6 & -16.0 \\
\hline
\end{tabular}

Notes: The expected duration (expected time to employment) is calculated by setting the covariates equal to the sample averages. The assumed month of inflow is February 2001. The unemployment rate is set to 11 percent and assumed constant over time and the hazard rate is taken as constant after the $60^{\text {th }}$ week. Bootstrapped confidence intervals in parentheses (95 percent) and squared brackets (90 percent). Intervals that imply statistically significant changes, relative to the period before July 2001, are italicized. 
A look at the estimated hazard profiles in Figure 7 and Figure 8 suggests that continuity around week 20 may be a reasonable assumption, at least for men. Indeed, the continuity restriction is easily accepted for all groups except female $\mathrm{C}$ workers (Table 8). When continuity is tested in conjunction with no entitlement effect, the restrictions are decisively rejected for men ( $p \leq .022$ ) but weakly accepted for women ( $p \geq .065$ ).

Table 8. Wald tests for no jump at week 20 and no entitlement effect ( $p$-values).

\begin{tabular}{c|c|c}
\hline & Men & Women \\
\hline No jump & .135 & .717 \\
B 2001 & .859 & .277 \\
C 2001 & .761 & .231 \\
D 2001 & .352 & .364 \\
B, C \& D 2001 & .281 & .951 \\
B 2002 & .805 & .024 \\
C 2002 & .563 & .177 \\
D 2002 & .653 & .078 \\
B, C \& D 2002 & & .265 \\
B, C \& D 2001 \& 2002 & .712 & \\
No jump and no & & .510 \\
entitlement effects & & .165 \\
B 2001 & .011 & .065 \\
C 2001 & .003 & \\
D 2001 & .022 & \\
B, C \& D 2001 & .014 & \\
\hline
\end{tabular}

Notes: The null hypotheses for no jumps are $\alpha_{1}^{j}=\alpha_{2}^{j}$ for 2001 and $\beta_{1}^{j}=\beta_{2}^{j}$ for 2002, j= B, C, D. The null hypotheses for no entitlement effects of the 2001 reform are $\alpha_{0}^{j}+\alpha_{1}^{j} 20=0, j=\mathrm{B}, \mathrm{C}, \mathrm{D}$.

From theory we expect $\alpha_{1}^{j}>0$, as discussed in a previous section; the job finding rate should increase as the unemployed worker approaches exhaustion of supplementary benefits. This is decisively rejected for men where the estimated slope parameters are negative, and statistically significant in two out the three cases. The estimates for women are more in line with theory: the estimated slopes are positive, and statistical significance obtains in two out of the three cases. 


\section{Discussion}

We have scrutinized the estimates by a number of sensitivity checks. One concern is how labor market conditions evolve around the reform dates for the treatments and the controls. Our basic specification includes variables that capture time-varying local labor market conditions and time dummies that control for common cyclical and seasonal effects. We have in addition estimated models with time-varying vacancy rates that are specific to the individuals' occupations and local labor markets. The results are virtually identical to those presented in the text.

We have also examined the time profile of the reform effects by more flexible specifications that allow the effects of the two-tiered system to vary week by week. ${ }^{17}$ The patterns in the data are reasonably well approximated by our chosen functional form and the overall results remain unaffected. A number of other sensitivity checks have also been undertaken. All in all, the results we have presented are robust to these checks.

The striking differences in the estimates for males and females are puzzling. ${ }^{18}$ Although omitted demand side variables could be an explanation, we find it implausible in light of our sensitivity checks. A more plausible suspect has already been discussed, viz. the child care reforms introduced in 2001 and 2002. The 2001 reform increased access to child care for unemployed parents with children, a reform that is analogous to a reduction in search costs. Although this should encourage job search and speed up job finding, it is not obvious that it should have markedly different effects across individuals with different market wages. The 2002 reform, however, can plausibly be expected to have an especially strong effect among individuals with relatively favorable market opportunities since the progressivity of the fee structure was reduced. We conjecture that this could be one explanation of the apparently anomalous finding that female unemployment duration declined after reforms that made the

\footnotetext{
17 In terms of Figure 5, this involves estimation of the slope up to week 20 by means of dummy variables that allow the slope to take any form.

18 There appears to be rather little systematic research on gender differences in job search and job finding behavior. The study by Røed and Zhang (2003) on Norwegian data finds that men are more responsive than women with respect to marginal changes in compensation whereas women are more responsive with respect to benefit exhaustion. The reasons for these differences are not clear.
} 
benefit system substantially more generous. Unfortunately, our data do not include sufficient information to seriously explore this possibility. ${ }^{19}$

The results for men and women are broadly similar in one respect, viz. the lack of action at the start of the spell: $\alpha_{0}^{j}$ is never significantly different from zero whereas theory would suggest a negative sign. Search effort has an immediate effect on job finding in the standard theory. This is clearly an oversimplification of actual labor markets where there can be substantial time lags between job applications and subsequent hiring decisions by employers. A decline in search effort would then appear as a decline in job finding at a later date. We conjecture that such time lags between search and job finding may be one reason for the lack of action at the start of the spell.

Our dating of reforms is based on when entitled benefits change, dates which are exogenous from the individual's perspective. In practice, however, it takes on average three to four weeks before entitled benefits appear as benefits received. The time lag is a consequence of the fact that actual benefit receipt is based on individual reports to the UI fund on unemployment experiences in the recent week(s). Actual benefit received is thus partly endogenous since it depends on individual decisions on when to deliver reports. The lag between a benefit change and actual benefit receipt may cause a lagged response to benefit reforms to the extent that workers are severely credit constrained and respond mainly to the level of current benefits, rather than current as well as future benefits. It is difficult to assess, however, whether or not this factor is of any importance.

In conclusion, our analysis cannot confirm that the benefit reforms had any adverse effects on overall unemployment duration. There is some evidence that male unemployment duration increased and some (weaker) evidence that female unemployment duration has fallen. There is strong evidence that the probability of job finding declined among men who have remained unemployed for more than 20 weeks. The differences in male and female responses are puzzling and should be subject for future research. In particular, it would be interesting to

\footnotetext{
19 The recent study by Spolander (2004) finds some support for the hypothesis that the Swedish child care reforms have increased female labor force participation.
} 
examine how job finding has responded among unemployed parents with small children, individuals who have been affected by child care reforms in addition to the UI reforms.

\section{References}

Card, D. and Levine, P. (2000). 'Extended benefits and the duration of UI spells: evidence from the New Jersey extended benefit program.’ Journal of Public Economics, vol. 78, 107-138.

Carling, K., Edin, P-A., Harkman, A. and Holmlund, B. (1996). 'Unemployment duration, unemployment benefits, and labor market programs in Sweden.' Journal of Public Economics, vol. 59, 313-314.

Carling, K. Holmlund, B. and Vejsiu, A. (2001). 'Do benefit curs boost job finding? Swedish evidence from the 1990s’, Economic Journal, vol. 111, 766-790.

Fredriksson, B. and Holmlund, B. (2001). 'Optimal unemployment insurance in search equilibrium.’ Journal of Labor Economics, vol. 19, 370-399

Hamermesh, D. (1979). 'Entitlement effects, unemployment insurance and employment decisions. Economic Inquiry, vol. XVII, 317-332.

Hamermesh, D. (1980). 'Unemployment insurance and labor supply.' International Economic Review, vol. 21, 517-527.

Harkman, A. (1997). 'Arbetslöshetsersättning och arbetslöshetstid - vilken effekt hade sänkningen från 90 till 80 procents ersättningsnivå? (Unemployment compensation and unemployment duration - what was the effect of the cut in the replacement rate from 90 to 80 percent?).’ In (A. Harkman, F. Jansson, K. Källberg and L. Öhrn, eds.) Arbetslöshetsersättningen och arbetsmarknadens funktionssätt (Unemployment Insurance and the Functioning of the Labour Market). The Swedish National Labour Market Board, Stockholm.

Katz, L. and Meyer, B. (1990). 'The impact of the potential duration of unemployment benefits on the duration of unemployment.' Journal of Public Economics, vol. 41, 45-72.

Lalive, R. and Zweimuller, J. (2004). 'Benefit entitlement and unemployment duration: The role of policy endogeneity.’ Journal of Public Economics, vol. 88, 2587-2616.

Lancaster, T. (1990). The Econometric Analysis of Transition Data, Cambridge University Press.

Mortensen, D. (1977). 'Unemployment insurance and job search decisions.' Industrial and Labor Relations Review, vol. 30, 505-517. 
Mortensen, D. (1990). 'A structural model of unemployment insurance benefit effects on the incidence and duration of unemployment.' In (Y. Weiss and G. Fishelson, eds.) Advances in the Theory and Measurement of Unemployment. Macmillan Press.

Røed, K., Jensen, P. and Thoursie, A. (2002). 'Unemployment duration, incentives and institutions - A micro-econometric analysis based on Scandinavian countries. Working Paper, Department of Economics, University of Oslo.

Røed, K. and Zhang, T. (2003), 'Does unemployment compensation affect unemployment duration?’ Economic Journal, vol. 113, 190-206.

Skolverket (2003), 'Uppföljning av reformen maxtaxa, allmän förskola m.m.' Stockholm: Skolverket.

Skolverket (2004), 'Barns omsorg.' Stockholm: Skolverket.

SOU (1996:51). Grundläggande drag i en ny arbetslöshetsförsäkring - alternativ och förslag (A New System for Unemployment Insurance - Alternatives and Proposals). Stockholm: Fritzes.

Spolander, S. (2004), 'Effects of the child care maximum fee on female labor supply in Sweden.’ Master thesis, Department of Economics, Uppsala University.

Statistics Sweden (1993). Studie av arbetslösa enligt AMV och enligt SCB, Bakgrundsfakta till arbetsmarknads- och utbildningsstatistiken (A study of the unemployed according to data from the employment agencies and the labour force surveys). Stockholm: Statistics Sweden. 


\section{Appendix}

Table A1. Other estimation results.

\begin{tabular}{|c|c|c|c|c|c|c|}
\hline \multirow{3}{*}{ Parameter } & \multicolumn{3}{|c|}{ Men } & \multicolumn{3}{|c|}{ Women } \\
\hline & \multirow{2}{*}{\multicolumn{2}{|c|}{ Estimate }} & $p$-value & \multirow[b]{2}{*}{ Estimate } & se & \multirow[t]{2}{*}{$p$-value } \\
\hline & & & & & & \\
\hline \multicolumn{7}{|l|}{ Demographics } \\
\hline Age & -.010 & .006 & .078 & -.059 & .008 & $<.0001$ \\
\hline Age squared & .004 & .008 & .635 & .067 & .011 & $<.0001$ \\
\hline Other Nordic countries & -.124 & .051 & .014 & -.011 & .056 & .851 \\
\hline Other European countries & -.334 & .046 & $<.0001$ & -.470 & .062 & $<.0001$ \\
\hline Non-European countries & -.662 & .054 & $<.0001$ & -.670 & .074 & $<.0001$ \\
\hline \multicolumn{7}{|l|}{$\begin{array}{l}\text { Human capital and working } \\
\text { time flexibility }\end{array}$} \\
\hline Elementary school, < 9 yrs & -.107 & .026 & $<.0001$ & -.246 & .045 & $<.0001$ \\
\hline Elementary school & -.140 & .021 & $<.0001$ & -.155 & .033 & $<.0001$ \\
\hline High school (ref.) & 0 & & & 0 & & \\
\hline University, $<2$ years & -.108 & .028 & $<.0001$ & -.014 & .030 & .628 \\
\hline University & -.033 & .021 & .117 & .101 & .022 & $<.0001$ \\
\hline University, graduate level & .017 & .071 & .808 & -.091 & .075 & .221 \\
\hline $\begin{array}{l}\text { Work experience in } \\
\text { preferred occupation }\end{array}$ & .138 & .021 & $<.0001$ & .164 & .024 & $<.0001$ \\
\hline $\begin{array}{l}\text { Log wage prior to } \\
\text { unemployment }\end{array}$ & .447 & .145 & .002 & -.235 & .183 & .198 \\
\hline $\begin{array}{l}\text { Willing to take part-time } \\
\text { job }\end{array}$ & -.135 & .015 & $<.0001$ & -.120 & .018 & $<.0001$ \\
\hline \multicolumn{7}{|l|}{ Local labor market } \\
\hline Unemployment rate & -.018 & .003 & $<.0001$ & -.025 & .004 & $<.0001$ \\
\hline $\begin{array}{l}\text { Change in unemployment } \\
\text { rate }\end{array}$ & -.171 & .017 & $<.0001$ & -.088 & .024 & .0002 \\
\hline \multicolumn{7}{|l|}{ Previous unemployment } \\
\hline Days of unemployment & -.0008 & .00005 & $<.0001$ & -.0008 & .00007 & $<.0001$ \\
\hline One previous spell & .137 & .018 & $<.0001$ & .083 & .023 & .0003 \\
\hline More then one prev. spells & .273 & .020 & $<.0001$ & .119 & .028 & $<.0001$ \\
\hline \multicolumn{7}{|l|}{$\begin{array}{l}\text { Participation in labor market } \\
\text { program }\end{array}$} \\
\hline Training & -.743 & .035 & $<.0001$ & -.792 & .051 & $<.0001$ \\
\hline Work practice & -.190 & .044 & $<.0001$ & -.154 & .063 & .015 \\
\hline Other & -.581 & .072 & $<.0001$ & -.812 & .125 & 0001 \\
\hline \multicolumn{7}{|l|}{ Treatment group } \\
\hline B & .108 & .068 & .113 & -.084 & .080 & .293 \\
\hline $\mathrm{C}$ & .243 & .082 & .003 & -.150 & .124 & .229 \\
\hline $\mathrm{D}$ & .188 & .089 & .035 & -.223 & .138 & .105 \\
\hline
\end{tabular}

Notes: The estimates are from the basic specification with 18 reform parameters. All variables are dummies except age, age squared, unemployment, change in unemployment and days of unemployment (previous). Other included variables are those described in the text. Previous unemployment refers to open unemployment and program participation during three years preceding the spell. Days of previous unemployment is given for observations with at least one previous spell. 
WORKING PAPERS*

Editor: Nils Gottfries

2004:6 Bertil Holmlund, Sickness Absence and Search Unemployment. 38 pp.

2004:7 Magnus Lundin, Nils Gottfries and Tomas Lindström, Price and Investment Dynamics: An Empirical Analysis of Plant Level Data. 41 pp.

2004:8 Maria Vredin Johansson, Allocation and Ex Ante Cost Efficiency of a Swedish Subsidy for Environmental Sustainability: The Local Investment Program. 26 pp.

2004:9 Sören Blomquist and Vidar Christiansen, Taxation and Heterogeneous Preferences. 29 pp.

2004:10 Magnus Gustavsson, Changes in Educational Wage Premiums in Sweden: 1992-2001. 36 pp.

2004:11 Magnus Gustavsson, Trends in the Transitory Variance of Earnings: Evidence from Sweden 1960-1990 and a Comparison with the United States. 63 pp.

2004:12 Annika Alexius, Far Out on the Yield Curve. 41 pp.

2004:13 Pär Österholm, Estimating the Relationship between Age Structure and GDP in the OECD Using Panel Cointegration Methods. 32 pp.

2004:14 Per-Anders Edin and Magnus Gustavsson, Time Out of Work and Skill Depreciation. 29 pp.

2004:15 Sören Blomquist and Luca Micheletto, Redistribution, In-Kind Transfers and Matching Grants when the Federal Government Lacks Information on Local Costs. 34 pp.

2004:16 Iida Häkkinen, Do University Entrance Exams Predict Academic Achievement? 38 pp.

2004:17 Mikael Carlsson, Investment and Uncertainty: A Theory-Based Empirical Approach. 27 pp.

2004:18 N. Anders Klevmarken, Towards an Applicable True Cost-of-Living Index that Incorporates Housing. 8 pp.

2004:19 Matz Dahlberg and Karin Edmark, Is there a "Race-to-the-Bottom” in the Setting of Welfare Benefit Levels? Evidence from a Policy Intervention. $34 \mathrm{pp}$.

2004:20 Pär Holmberg, Unique Supply Function Equilibrium with Capacity Constraints. 31 pp.

\footnotetext{
* A list of papers in this series from earlier years will be sent on request by the department.
} 
2005:1 Mikael Bengtsson, Niclas Berggren and Henrik Jordahl, Trust and Growth in the 1990s - A Robustness Analysis. 30 pp.

2005:2 Niclas Berggren and Henrik Jordahl, Free to Trust? Economic Freedom and Social Capital. 31 pp.

2005:3 Matz Dahlberg and Eva Mörk, Public Employment and the Double Role of Bureaucrats. 26 pp.

2005:4 Matz Dahlberg and Douglas Lundin, Antidepressants and the Suicide Rate: Is There Really a Connection? $31 \mathrm{pp}$.

2005:5 Maria Vredin Johansson, Tobias Heldt and Per Johansson, Latent Variables in a Travel Mode Choice Model: Attitudinal and Behavioural Indicator Variables. 31 pp.

2005:6 Katarina Nordblom and Henry Ohlsson, Tax Avoidance and Intra-Family Transfers. 25 pp.

2005:7 Sören Blomquist and Luca Micheletto, Optimal Redistributive Taxation when Government’s and Agents’ Preferences Differ. 22 pp.

2005:8 Ruth-Aïda Nahum, Income Inequality and Growth: A Panel Study of Swedish Counties 1960-2000. 39 pp.

2005:9 Olof Åslund and Peter Fredriksson, Ethnic Enclaves and Welfare Cultures Quasi-experimental Evidence. 37 pp.

2005:10 Annika Alexius and Erik Post, Exchange Rates and Asymmetric Shocks in Small Open Economies. 31 pp.

2005:11 Martin Ågren, Myopic Loss Aversion, the Equity Premium Puzzle, and GARCH. 34 pp.

2005:12 Pär Holmberg, Numerical Calculation of an Asymmetric Supply Function Equilibrium with Capacity Constraints. 18 pp.

2005:13 Jovan Zamac, Winners and Losers from a Demographic Shock under Different Intergenerational Transfer Schemes. $44 \mathrm{pp}$.

2005:14 Peter Welz and Pär Österholm, Interest Rate Smoothing versus Serially Correlated Errors in Taylor Rules: Testing the Tests. 29 pp.

2005:15 Helge Bennmarker, Kenneth Carling and Bertil Holmlund, Do Benefit Hikes Damage Job Finding? Evidence from Swedish Unemployment Insurance Reforms. 37 pp.

See also working papers published by the Office of Labour Market Policy Evaluation http://www.ifau.se/ 